Portland State University

PDXScholar

$1-1-1983$

\title{
The impact of tourism on the pattern of economic activity in Portland, Oregon
}

\author{
Alphaeus O. Ohakweh \\ Portland State University
}

Follow this and additional works at: https://pdxscholar.library.pdx.edu/open_access_etds

\section{Let us know how access to this document benefits you.}

\section{Recommended Citation}

Ohakweh, Alphaeus 0., "The impact of tourism on the pattern of economic activity in Portland, Oregon" (1983). Dissertations and Theses. Paper 414.

https://doi.org/10.15760/etd.414

This Dissertation is brought to you for free and open access. It has been accepted for inclusion in Dissertations and Theses by an authorized administrator of PDXScholar. Please contact us if we can make this document more accessible: pdxscholar@pdx.edu. 
THE IMPACT OF TOUP.ISM ON THE

PATTERN OF ECONOMIC ACTIVITY

IN PORTLAND, OREGON

by
ALPHAEUS O. OHAKWEH

A dissertation submitted in partial fulfillment

of the requirements for the degree of

DOCTOR OF PHILOSOPHY

in

URBAN STUDIES

Portland State University

283 
TO THE OFFICE OF GRADUATE STUDIES AND RESEARCH:

The members of the committee approve the dissertation of Alphaeus 0 . Chakweh presented February 11, 1983.

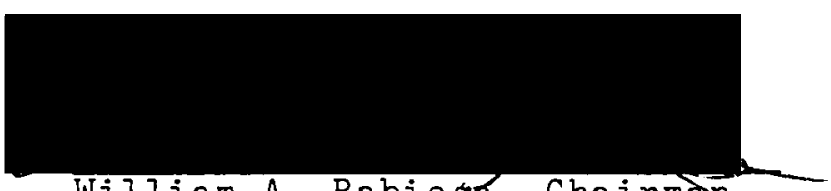

William A. Rabiega, Chairma

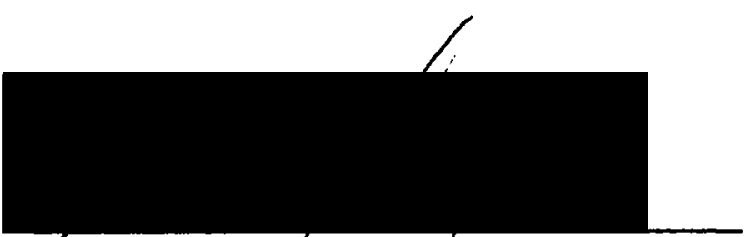

Nohad A. Toulan

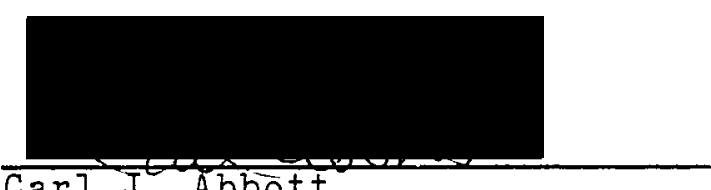

Carl J. Abbott
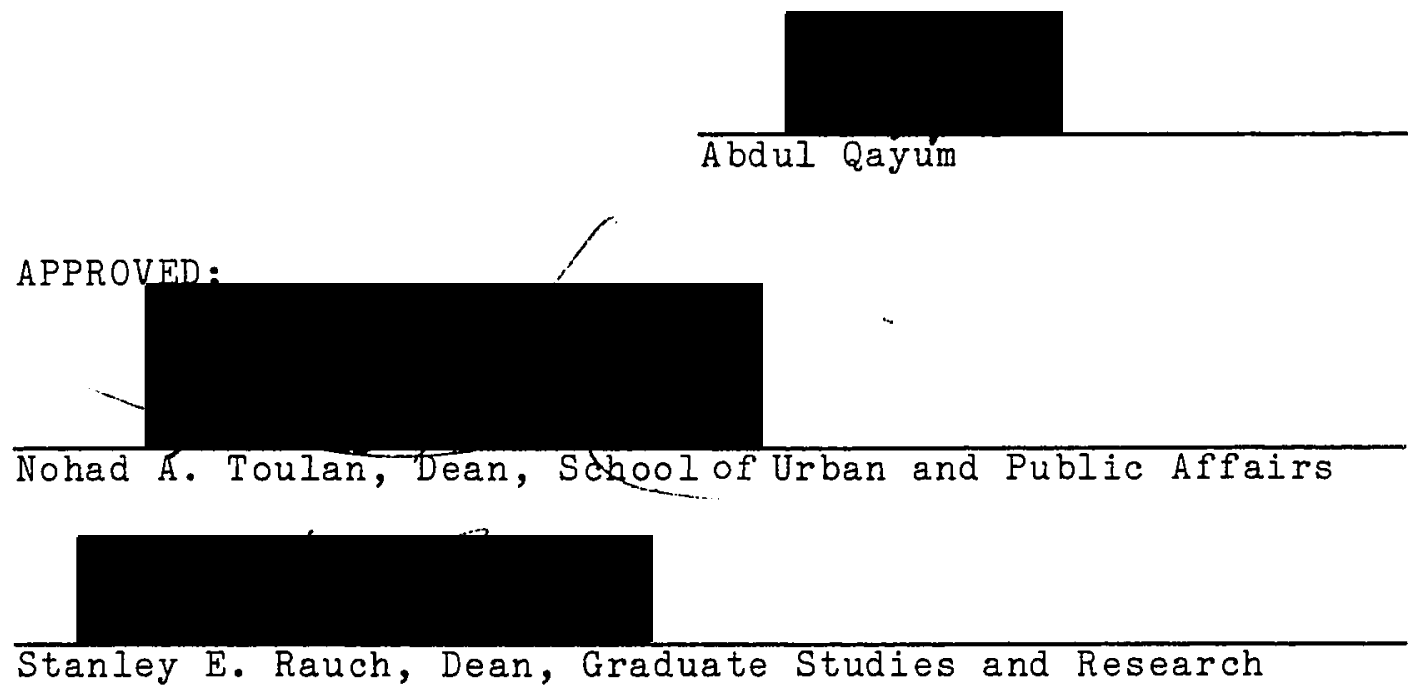

February 11,1983 
AN ABSTRACT OF THE DISSERTATION OF Alphaeus 0 . Ohakweh for the Doctor of Philosophy in Urban studies presented February 11, 1983.

Title: The Impact of Tourism on the Pattern of Economic Activity in Portland, Oregon.

APPROVED BY MEMBERS OF THE DISSERTATION COMMITTEE:

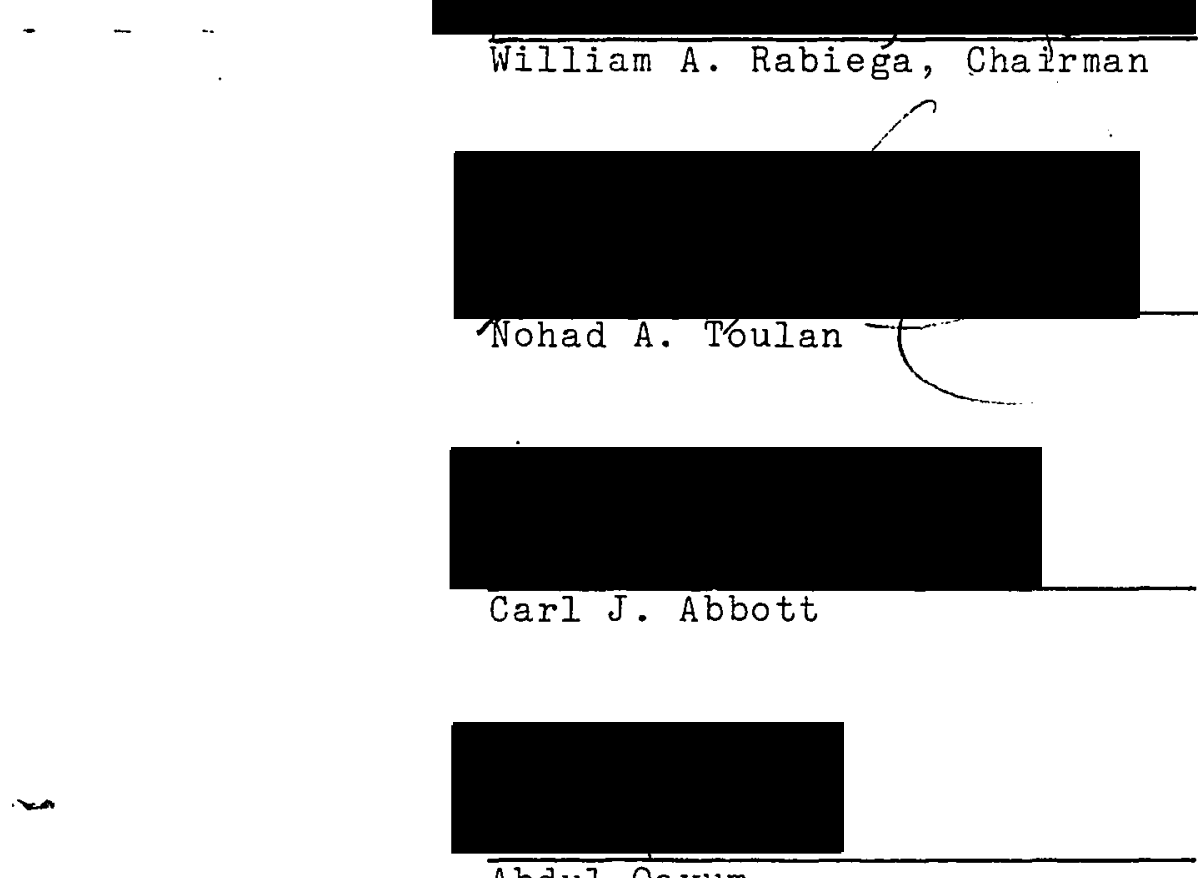

Abdul Qayum

This research focuses on the measurement of monetary benefits and costs associated with tourism in metropolitan areas. Most studies on the impact of tourism have been at the national or state level and are not directly appropriate to more limited geographic units. The planning 
agencies and Chambers of Commerce that are normally involved in promoting tourism work with the metropolitan area, a jurisdiction which is different from that on which most previous studies have been done. In this study, an answer to the following research question is sought: Do public expenditures attributable to tourism outweigh the revenue benefits derived from tourism in a metropolitan area, or is the taxpayer subsidizing the tourism industry?

The Portland metropolitan area was selected as a case on which to develop a methodology for ascertaining the economic impact of tourism. Since the tourism industry is extensively fragmented, data were collected from several sources to measure its impact. Using these data, a methodology for weighing monetary costs against benefits attributable to tourism was developed. Three methodological sequences were carried out in the study. The first two were models to compute income and employment multiplier effects. These models helped in the development of intermediate inputs applied in executing the last methodological sequence -- the monetary benefit-cost model.

The analytical findings strongly support the following two hypotheses: (1) Tourism provides significant enployment creation and income generation possibilities. (2) Tourism creates more benefits than it causes service costs to the metropolitan area. For example, it was found that the income and employment multiplier effects from tourists' spendings in the area were 1.1024 during the study 
period. Also, while the metropolitan area spent $\$ 27,873,133.80$ in providing services to tourists, it realized $\$ 33,516,481.17$ in monetary benefits from tourists' spendings. When monetary costs were subtracted from benefits, the metropolitan area realized a net monetary benefit of $\$ 5.6$ million from tourists' spendings in the area. 


\section{ACKNOWLEDGMENT}

I would like to acknowledge the following individuals whose assistance helped me immeasurably in the completion of this dissertation. First, I would like to thank Dr. William A. Rabiega, who kindled my inspiration on the topic of the dissertation, and who, as the chairman of my committee, relentlessly provided his expert guidance. I also want to express my gratitude to my advisor, Dr. Nohad A. Toulan, not only for his efforts in this particular, but also for his role in my more general scholarly development. During the period of our association, I have come to regard him as a friend as well as a mentor. My appreciation also extends to the other members of my dissertation committee: Dr. Carl J. Abbott, for his editorial advice, and Dr. Abdul Qayum, for his critical comments and analytical assistance.

This dissertation was completed while I was the 1982 recipient of the Multnomah County doctoral fellowship award, administered through the School of Urban Affairs, Portland State University. I am very grateful to Multnomah County for providing the funds for this fellowship.

I am especially indebted to Dr. Stefano Zegretti, as he acted virtually as a second advisor to me when this topic was in the proposal stage. I alsowish to express my thanks to Dr. Tom Gihring and Dr. Morton Paglin for their valuable comments. I owe special thanks to Mr. Dan Vizini of the Multnomah County Tax Supervising and Conservation Commission 
for his continued assistance to me in locating the hard to find data. I am grateful to the Custom Business Analysis for their excellent typing skills. Finally, my appreciation goes to my wife, Philomina, for her inspiration and assistance, and to my ailing mother, Janet, who has prayed for so long to see me before her last breath. 
TABLE OF CONTENTS

PAGE

ACKNOWLEDGMENT .............................. ii

LIST OF TABLES..................... $\mathrm{x}$

LIST OF FIGURES....................... xi

CHAPTER

I INTRODUCTION.................. 1

Background.............. 1

Some Problems with Measuring

Tourist Impact................ 2

Tourism as an Export Industry.... 4

The Research Problem......... 5

Study Area............... 8

Organization............. 8

II LITERATURE REVIEW.............. 10

THE RELATION OF TOURISM TO THE

ECONOMIC BASE THEORY............. 10

Determining the Extent of Basic and Nonbasic Activities and the Base

Multiplier.................. 12

THE MULTIPLIER PRINCIPLE.......... 15

Multiplier Effects of Tourist

Spending................. 16

MONETARY BENEFITS AND COSTS......... 19

Monetary Benefits........... 20

Monetary Costs.............. 22

Calculating Monetary Benefits

and Costs................. 22 
II Data Used in Tourist Impact

Studies.................. 23

III METHODS AND DATA.............. 29

Who is a Tourist?........... 30

Research Questions and Hypotheses. 31

DESIGN........................... 32

Field Area and Time Period...... 33

DATA SOURCES AND TYPES........... 35

Secondary Data Sources......... 36

Primary Data Sources and

Method of Collection.......... 45

IV THE MULTIPLIER AND MONETARY

BENEFIT-COST MODELS. . ........... 49

BENEFITS................... 51

Direct Monetary Benefits........ 51

Indirect Monetary Benefits...... 52

Calculating Monetary Benefits.... 53

Income Multiplier Model......... 59

Step $1 \ldots \ldots \ldots \ldots \ldots \ldots \ldots \ldots . \ldots \ldots$

Step $2 \ldots \ldots \ldots \ldots \ldots \ldots \ldots \ldots . \ldots \ldots$

Step $3 \ldots \ldots \ldots \ldots \ldots \ldots \ldots \ldots \ldots$

Step $4 \ldots \ldots \ldots \ldots \ldots \ldots \ldots \ldots . \ldots 6$

Step $5 \ldots \ldots \ldots \ldots \ldots \ldots \ldots \ldots . . \ldots 6$

Step $6 \ldots \ldots \ldots \ldots \ldots \ldots \ldots \ldots . \ldots . \ldots 6$

Step $7 \ldots \ldots \ldots \ldots \ldots \ldots \ldots \ldots . \ldots 6$

Step $8 \ldots \ldots \ldots \ldots \ldots \ldots \ldots \ldots . \ldots 6$

Step $9 \ldots \ldots \ldots \ldots \ldots \ldots \ldots . \ldots . \ldots 6$ 
Employment Multiplier Model..... 66

MONETARY COSTS............. 66

Calculating Tourist Monetary Costs 68

Weighing Monetary Benefits Against

Costs.................... 70

V ANALISIS OF DATA............... 71

RESEARCH MODEL COMPUTATIONS......... 71

Income Multiplier........... 71

Step $1 \ldots \ldots \ldots \ldots \ldots \ldots \ldots \ldots \ldots \ldots$

Step $2 \ldots \ldots \ldots \ldots \ldots \ldots \ldots \ldots \ldots \ldots$

Step $3 \ldots \ldots \ldots \ldots \ldots \ldots \ldots \ldots \ldots$

Step $4 \ldots \ldots \ldots \ldots \ldots \ldots \ldots \ldots . \ldots \ldots$

Step $5 \ldots \ldots \ldots \ldots \ldots \ldots \ldots \ldots . \ldots \ldots$

Step $6 \ldots \ldots \ldots \ldots \ldots \ldots \ldots \ldots$

Step $7 \ldots \ldots \ldots \ldots \ldots \ldots \ldots \ldots . \ldots \ldots$

Step $8 \ldots \ldots \ldots \ldots \ldots \ldots \ldots \ldots \ldots$

Step $9 \ldots \ldots \ldots \ldots \ldots \ldots \ldots \ldots . \ldots . \ldots . \ldots 76$

Employment Multiplier......... 77

Tourist-Generated Business

Property Tax Revenues.......... 82

Tourist-Generated Business

License Revenues............ 87

Tourist-Generated Fuel Tax and

Room Occupation Tax Revenues..... 89

Tourist-Generated Revenues from Public Amusement and Recreation

Facilities, and Parking Revenues.. 90

Property Taxes Paid by People

Employed Due to Tourist Spending.. 92 
Computing Monetary Costs........ 98

Comparing Costs with Benefits.... 99

VI FINDINGS AND VALIDATION OF METHOD.... 100

Hypothesis No. 1............ 100

Hypothesis No. 2............ 101

Minor Hypothesis............ 102

Other Findings.............. 104

VALIDATION OF METHOD............ 105

Validating the Research

Data and Method............. 106

VII SUMMARY, DISCUSSION AND CONCLUSION.... 111

SUMMARY....................... 111

DISCUSSION.................. 112

Merits of the Study........... 119

Limitations of the Study........ 121

CONCLUSIONS................... 123

Future Research.............. 124

BIBLIOGRAPHY........................... 126

APPENDICES

A QUESTIONNAIRES USED IN SURVEYS OF

HOTELS AND MOTELS.............. 138

B QUESTIONNAIRES USED IN SURVEYS OF

EATING AND DRINKING ES'TABLISHMENTS,

GASOLINE SERVICE STATIONS, MOVIE

THEATRES AND MISCELLANEOUS RETAIL

ST OR ES ...................... 140

C QUESTIONNAIRES USED IN SURVEYS OF HOTEL AND EATING-DRINKING ESTABLISHMENTS'

MANAGERS ON TIPS............... 142 
D DETAILED: METROPOLITAN PORTLAND EXPENDITURES BY COUNTY 1980-81....... 143 


\section{LIST OF TABLES}

TABLE

PAGE

I Volume and Pattern of Tourist Spending..

II Percent of Tourist Expenditures That

Remain in Metropolitan Area as

Income................... 73

II Sales Per Employee by Business

Category Portland S.M.S.A.

$1977-1980 \ldots \ldots \ldots \ldots \ldots \ldots \ldots \ldots \ldots$

IV Volume and Pattern of Tourist

Spending With Employment by Sector... 80

$\mathrm{V}$ Tourist-Generated Employment

That Remained in the Metropolitan

Area.....................

VI Tourist-Related Businesses:

Sample Assessed Values and

Property Taxes................. 84

VII Tourist-Related Businesses:

Estimated Values and

Property Taxes................. 85

VIII Tourist-Generated Business

Property $\operatorname{Tax}$ Revenues............ 86

IX State Required Tourist-Related

Business License Revenue:

Tri-County Area............... 
X All Cities Tourist Related

Business License Revenues.......... 89

XI Tourist-Generated Revenues From

Public Amusement \& Recreation

Facilities.................. 91

XII State of Oregon Annual Earnings

per Employee by Type of Business..... 93

XIII Direct Tourism-Generated

Employment Earnings in the

Metropolitan Area 1980........... 94

XIV Total Metropolitan Property Tax

Revenues by County.............. 96

XV Metropolitan Tourism Induced

Revenues.................... 97

XVI Summary: Metropolitan Portland

Expenditures $1980-81 \ldots \ldots \ldots \ldots \ldots$....... 98

XVII(a) Total Tourism-Generated Income......... 101

XVII(b) Total Tourism-Generated Employment..... 101

XVIII Distribution of Tourist Generated-

Employment................ 103 


\section{LIST OF FIGURES}

FIGURE

PAGE

I General Outline Map of Portland

S.M.S.A................... 34

II General Outline of Research

Models.................... 50 
CHAPTER I

INTRODUCTION

Background

Traditionally, the two ways to bring about economic development in metropolitan areas have been expansion in manufacturing and commerce. 'roday, tourism is recognized as an alternative way to build a stable economy. Tourism literature, reports in trade journals, and popular magazines (Lundberg, 1973, McIntosh, 1973, and Clawson and Knetch, 1966), optimistically expound the benefits of stabilizing an economy through expansion of the tourist trade. Limited attention, however, has been given to the potential liabilities that may arise due to economic dependence on tourism. George Young, in his book, Tourism: Blessing or Blight? (1973), explores this other side of the question. He advances a hypothesis that there is a saturation level for tourism in any metropolitan area and believes that if this level is exceeded, the costs of tourism begin to outweigh the benefits. Hence, to fully understand the economic impact of tourism on a tourist destination area, particularly a metropolitan area, an answer to the following general research question must be provided: Does tourism bring more into the economy than it takes out? 
Some Problems with Measuring Tourist Impact

While the question appears superficially to be a straightforward one, in fact it is fraught with complications. At least four major problems are encountered in carrying out in-depth analyses of tourism's impact on highly specified destination areas. The first is the absence of a universal definition of a "tourist." Most of the studies on the impact of tourism have been made at the national or state level and therefore are not directly appropriate to more limited geographical units. These studies have produced varied definitions. For example, a Florida study defined a tourist as an out-of-state resident who stays in the state for at least one night for reasons other than strictly business transactions (Florida Development Commission, 1965), while an Alaska study (Hinkson, 1964), defined a tourist as a nonresident traveling to Alaska extensively for pleasure or culture. A West Virginia study (Rovelstad, 1977), used minimum distance traveled as the criterion for defining a tourist instead of more traditional criteria, e.g., motivation or trip purpose and length of stay. In this research project tourists are defined as anyone traveling into the metropolitan area (south of the Columbia River), for at least twenty-four hours. This definition is less restrictive than the previous ones and will be discussed in more detail in Chapter III.

The second major problem is one of defining what comprises the tourism industry. Rovelstad (1977) has described 
it as a collage of various sized firms from many industries, which stresses its fragmented nature. Contemporary marketing concepts define business goals in terms of consumer needs served, rather than in terms of products produced. The tourism industry can be so defined, but this adds to more confusion because many other industries still use the product concept, e.g., the automobile industry and the coal industry. Regardless, the tourism industry can be defined as any business or trade and the facilities which directly serve or facilitate the needs of tourists in a tourist destination area (Goeke, 1981). However, Lundberg (1973) noted that the business categories which loom largest in economic importance vary with the tourist destination area or region.

A third problem is that although the literature shows that the input of tourism into local or metropolitan economies may be substantial, it is also clear that little is known about the various costs (Peters, 1969; Archer and Owen, 1971). Very few studies have attempted to assess the impact of tourism on employment, income, tax revenues, or other indicators of economic activity. Furthermore, the findings of some of these few studies are generally reported in papers and publications not easily accessible to other tourism researchers, e.g., state economic development and highway reports-bulletins and reports to various agencies of the federal government. This substantially limits communication among researchers. 
The fourth problem is related to the first in terms of scale of the study. The planning agencies and Chambers of Commerce that are normally involved in promoting tourism generally work within a metropolitan area, a jurisdiction different from the subject matter area of most previous studies. Since these studies largely have been conducted on a national or state level (or even the level of a specific project), no methodology has been developed for assessing total tourist impacts on a metropolitan level.

\section{Tourism as an Export Industry}

Tourism as an export industry is tremendously important to the economic well being of most large cities. Services rendered to tourists are exports because the tourist dollar is a fresh dollar to the economy. Economic base theory holds that the rate and direction of growth in a metropolitan area is determined by its exports (Bendavid, 1974). This theory divides the local economy into two sectors: basic and nonbasic. The basic sector is that which sells goods and services to other areas, and the nonbasic sector sells goods and services to the local population. The scope of businesses in the tourism industry is suggested by considering the services, goods and activities tourists tend to use, or in which they participate. The problem is that many businesses do not fall neatly into one of the two categories. For example, several basic businesses also receive substantial, or even principal use from 
local residents, which presents a difficulty in determining what portion of these businesses may be considered basic and what part nonbasic. However, an allocation formula based on percentage sales to tourists (Goeke, 1981; Weaver et al, 1978) can be used to determine what portion of these businesses' transactions are export transactions. An analysis of tourist impact normally looks at a portion or segment of employment and revenues from these sectors rather than total employment and revenues. The nature of the tourist business is such that it permeates the business community in terms of its multiplier effects. For example, increased tourist business in many of the restaurants, service stations, gift shops, sporting goods stores, hotels and motels, campgrounds, amusement and recreation places, means added income to business proprietors and to the metropolitan economy. When proprietors pay out money in wages and salaries, supplies, interest, rent, taxes, etc., they add to metropolitan income (clement, 1961). This process continues as the money flows through the metropolitan economy, but to a lesser degree as leakage inceasingly sets in.

\section{The Research Problem}

This dissertation investigates whether the benefits due to tourism outweigh the costs of maintaining the tourists during their stay. That is, it explores the benefit-cost questions as they relate to tourism. Many costs are 
associated with tourism, e.g., environmental, service and social costs. On the other hand, many benefits ensue from tourism, e.g., increased business and employment due to tourist spending in the area, increased tax revenues, and image enhancement through increased publicity. This analysis looks at a specific segment of the benefit-cost question rather than the total benefits and costs of tourism. The segment covered is revenues and expenditures of public funds. When tourists visit a metropolitan area, the local government incurs costs in providing such services to tourists as public safety (police and fire protection), sewer and water service, roads and streets, parks and recreation, etc. On the other hand, the metropolitan government benefits from increased tax revenues due to tourist spending and user fees. The benefit-cost model is formed by weighing the monetary or service costs incurred against the revenues derived from tourist spendings.

The benefit-cost model developed in this research slightly deviates from the traditional benefit-cost model (Clawson and Knetsch, 1966; Prest and Turvey, 1965), whereby capital expenditures, equipment or structures are arbitrarily discounted to the present values. The research problem does not lend itself to that type of approach because physical structures and their present values are not the main issue at stake. Rather, the main thrust of the dissertation is a comparison of the visible costs of providing public services to tourists in a typical year 
with revenues from that year derived from tourism. The alternative to benefit-cost analysis is the opportunity cost concept. This concept relies on values of benefits that are lost by choosing one alternative rather than the other (Spenser, 1974). That is, if a portion of metropolitan populace are not involved in the tourism industry, what other economic activity might be an alternative? Would the metropolitan area derive more revenues and incur fewer service costs from that alternative? For people employed in tourism, apparently no significant opportunity costs are involved. This is mainly because of the flexible working hours available in the tourism industry, for people who have other jobs, but need second jobs to supplement their income, or people who would choose not to seek employment in the traditional sectors while going to school. Thus as indicted earlier, the emphasis in this research is not ajmed at depreciating capital, structures and equipment because a fixed capital like a bridge or highway is not involved. Rather, the study looks at benefits and costs in terms of metropolitan annual operating costs and revenues. With the above discussion, there are good reasons to believe that opportunity costs are not an important issue here. Hence, the model developed in this study involves derivation of average metropolitan costs per person-day and average revenues per tourist person-day.

Also this research explores the income and employment multipliers of tourist spending in the metropolitan area, 
the emphasis here is not to develop a multiplier model that relies heavily on the basic and nonbasic concept of economic activities. Rather, realizing the export nature of tourism and given "the pattern and volume of tourist spending" in a year, what multiplier effect does this amount of spending have on the metropolitan economy? ${ }^{1}$

\section{Study Area}

This analysis centers on the Portland metropolitan area south of the Columbia River in the State of Oregon. This is a reasonable end destination for tourists because of the important urban amenities the area provides. It is a principal commercial center in the state, and there are majur events and unusual natural scenic attractions that draw tourists to the area: the Rose Festival, the Mount Hood Jazz Festival, Professional Basketball Games, the Pacific Coastal Range, the Mount St. Helens volcanic eruptions, etc.

\section{Organization}

The points raised in this introduction will be taken up and treated in more detail in the following chapters. The chapters are organized as follows: Chapter II will review literature bearing on the study. The purpose is not to do

\footnotetext{
1 The Portland metropolitan area is made up of four counties: three in the state of Oregon (Multnomah, Clackamas and Washington counties) and one in Washington State (Clark county).
} 
an exhaustive reiteration of all extant literature, but to position the study within the research tradition. Chapter III brings the literature and research problem into relation. It will develop the conceptual basis of the study, thus defining who is a tourist as well as stating the research questions and hypotheses. Also, the research data and methods of collection are discussed. In Chapter IV, the three research models, the income and employment multiplier models, and the monetary benefits and costs model as applied in the study are fully elaborated. Chapter V concentrates on testing the research methods with the pertinent data collected. In chapter VI, the study findings in relation to the research questions and hypotheses are presented, and the methods are validated accordingly. Chapter VII explores the dissertation's analytical results for more general findings. It then summarizes all that has been done and draws the discussions together into a concise statement of research conclusions. 


\section{CHAPTER II}

\section{LITERATURE REVIEW}

This chapter presents and assesses the background thinking which forms the framework for assessing the tourism impact on the economy of tourist destination areas. The literature falls into four categories. The first approaches tourism as an export activity and discusses its multiplier effects in relation to income and employment. Ian Masser (1972), stated that the concept of multiplier refers to the effect that a given increase in expenditure will ultimately have on the increase in metropolitan or regional incomes or employment as a whole. The second deals with the volume and pattern of tourist spending and their relationship to tax revenues. In the third, public expenditures in terms of metropolitan costs of providing services to tourists are detailed. Lastly, sources of data for tourism study are reviewed. The purpose here is not to present an exhaustive review of all extant literature, but to show that literature dealing with the multiplier theory, tourist spending patterns, cost of services to tourists, plus some empirical Iiterature, are important bases for the research undertaken in this project.

THE RELATION OF TOURISM TO THE ECONOMIC BASE THEORY

Economic base theory holds that the rate and grow th of a region or metropolitan area is determined by its exports 
(Bendavid, 1974). It divides the metropolitan economy into two sectors -- the basic and the nonbasic. The basic sector refers to those economic activities of a community which involve the export of goods or services to firms or individuals who live and gain their incomes from locations beyond the boundaries of the community in question (Pfouts, 1960). Basic activities can be classified into two broad categories: (1) ones that move goods and services to the consumer purchaser and, (2) ones that attract the consumer to goods and services. The first category involves those basic activities of a metropolitan area which are engaged in the export of merchandise outside the limits or boundaries of the area. This is perhaps most familiar and easily identifiable as "basic" activity, for example, manufacturing and/or growing of wheat. The second category is one in which the consumer enters the area where the basic activity is located and, for the most part, consumes the services on the spot. Tourism-related businesses such as hotels, motels, restaurants, gift and souvenir shops, gasoline service stations, amusement and recreation establishments, etc. are examples. The tourist, being an on-the-spot consumer, exchanges capital brought from outside for goods and services which are available in the area. The economic effect of these basic activities is such that a net inflow of dollars is created for the subject metropolitan area. These dollars may balance or overbalance the spendings of the area for goods and services. Thus, jobs and income derived from 
this type of basic activity are significant for economic growth (Lundberg, 1973; Pfouts, 1960).

On the other hand, the nonbasic sector refers to those metropolitan economic entities, which do not engage in export activity, but sell their products or services locally to basic enterprises, other nonbasic entities and the unemployed. Some tourist-related businesses which were defined above as basic may also be considered to have nonbasic aspects, for example, restaurants, gasoline service stations, recreation and amusement establishments, souvenir shops, etc. In other words, businesses which may exist principally as tourist industries, may also receive substantial or even principal use from local residents. Tourism cuts vertically through the traditional division of economic activities by product or service sectors; hence Rovelstad's apt description of tourism as a collage of various sized firms from many industries. This cross-cut nature of tourism makes it difficult to determine what portion of tourist-related businesses are basic and what part are nonbasic.

Determining the Extent of Basic and Nonbasic Activities, and the Base Multiplier

There are several general techniques whereby basic and nonbasic activities can be determined and their impact measured. The units of measurement used include value added, physical production, employment, and income (Tiebout, 
1962; Moody, 1970). The most commonly used units are income and employment (Andrews, 1954; Garrison, 1972; Lewis, 1976; and Thompson, 1959), because of their compatibility and utility. Employment can be easily converted to income and vice versa. The techniques of measurement fall into two broad categories: direct and indirect measures of the local economy. The direct measure involves surveys of firms and people through personal, telephone or mail questionnaires. The information sought is family income and where it was earned geographically. Information required from firms includes purchases and seller information, total sales figures, expenditures, and number of employees. Statistically, total sales may be expressed as percentages rather than as dollars mainly to avoid a disclosure concern held by some firms (Tiebout, 1962).

The economic base with its multiplier distinguishes between the basic and nonbasic sectors by reference to two types of market areas: The locally-produced goods and services which are exported for sale outside the study area (basic) and locally produced goods and services which are consumed within the study area (nonbasic). This becomes important as a means of prediction when it is applied within the general context of the multiplier. In relation to the export base, multiplier generally refers to the ultimate income increase in a metropolitan area resulting from an increase in the basic sector. In general terms, the base 
multiplier may be represented as $K=\frac{Y}{X}$

where $K=$ the multiplier

$\mathrm{Y}=$ the metropolitan income or employment

$X=$ the total basic income or employment

and $Y=D+X$

where $D$ = locally derived (nonbasic) income or employment. In incremental terms, the multiplier may be expressed as

$$
K=\frac{\Delta Y}{\Delta X}
$$

where $\Delta=$ change in $Y$ or $X$

The model implies that the basic sectors are viewed as the main stay to the economic existence of a metropolitan area, while the nonbasic sectors are ultimately dependent on the scale and success of the basic sectors. There are areas, for example Pittsburgh with its steel industry and Detroit with its automobile industry, where the basic sectors certainly dominate the economy. However, this method is not suitable for areas not dominated by their basic industries (Helly, 1975), or for tourism multiplier analysis where the industry (tourism) is a collage of various size firms that receive substantial, if not principal, use from residents and at the same time from tourists that frequent them. Given the conceptual problems with the economic base theory, its associated multiplier and the problems of application discussed above, what better alternatives are available to the analyst who must predict the total impact (both direct 
and indirect) of tourist spending in a tourist destination area? Solutions to the above question are provided in the discussions that follow.

\section{THE MULTIPLIER PRINCIPLE}

One of the important concerns of macroeconomics relates to how changes in spending will affect the level of metropolitan income. The multiplier principle was first enunciated by Professor Paul A. Samuelson (1939). It states that an increase in net spending will cause a magnified increase in income and output (Spencer, 1974). Likewise, decrease in net spending will cause a magnified decrease in income and output. Hence, the amount by which a change in spending is multiplied to produce an ultimate change in income and output is the multiplier. Michael Peters (1969), stated that with tourism, the definition applied should be the change in income generated by an increase or decrease in expenditure by tourists in the area. Starting from a position of equilibrium, a rise in expenditure by tourists will produce a rise in metropolitan income, and a fall will lower it. Therefore, tourist-generated income or employment in a metropolitan area will vary directly with expenditure by tourists. It then becomes necessary to consider the quantitative magnitude of this relationship. If there is an increase in expenditure by tourists of $\$ \mathrm{X}$ million, by how much will income and employment rise, both directly and indirectly? 
Multiplier Effects of Tourist Spending

When a fresh dollar from tourist spending enters an economy, it affects that economy in various ways because the direct impacts, sales, and profits create indirect impacts. The multiplier effect can be very significant. The money spent by the tourist in, say, paying his hotel bill, has a direct impact on the economy. The indirect effects of this expenditure arise from purchase of those goods and services demanded by tourists. Therefore, there are two links between tourist spending and the economy: (1) broad consumption items, which have a direct effect, and (2) the lirks between the sectors directly involved with tourists and those sectors and industries which supply the tourist related sectors with goods and services. Every time the tourist dollar chaiges hands, it provides new income; and the various conversions of the money spent by tourists forms what is called the multiplier effect. The more times the tourist dollar is recycled, the higher the multiplier and the greater its beneficial effect on the economy. However, leakages ultimately reduce or stop the cycle. These leakages can be in the form of payments for imported goods and services, or when much of the profits go out of the area.

Several factors affect the size of the multiplier. Income which accrues to local residents depends upon the size of tourist spending. Generally, the more tourists who visit an area and the more money they spend, the greater the local income. However, the exact size of income and the 
number of jobs created also depend on the pattern of tourist expenditure. Goods and services with a high wage and net profit content add more to the metropolitan economy than do those with a higher leakage element (Archer and Owen, 1971). Therefore, the specific type of tourist-related activity in question and the kinds of expenditures it generates are of important consideration. Expenditures at gasoline service stations, for example, return less income to the local or metropolitan economic system than do equal expenditures on other items such as lodging. This is explained, in part, by the large number of transactions that take place between gasoline service stations and general wholesalers. Wholesale firms supplying the gasoline service stations may not be located in the metropolitan area, or their product may be imported. In contrast, expenditures on lodging are more likely to accrue as metropolitan income, since a high percentage of suci expenditures are translated into wages for local labor or payments to local suppliers of goods and services. A southwestern Wyoming study produced the following income multipliers: 1.98503 for gasoline stations, 2.29230 for eating and drinking establishments, and 2.00290 for other retail establishments. According to the study, households received induced income for each dollar of expenditure in the three sectors as follows: $\$ 0.24$ from gasoline stations, $\$ 0.42$ from eating and drinking establishments, and $\$ 0.34$ from other retail establishments (Kite and Schutz, 1967). 
Another example of the way in which the functional organization of a tourist-related business in the metropolitan area may contribute to variations in income effects may be seen by an examination of the establishments. Franchises generally purchase supplies from centrallylocated commissaries. Consequently, tourist expenditures at such businesses are likely to have fewer multiplier effects on a local economy than equal expenditures at nonfranchised establishments, which tend to purchase a higher percentage of their supplies locally. Also important is the amount of goods and services produced locally with consequent percent of local income that is spent locally. This is important because the wider an area's economic base is or the more self-contained the local economy is, the fewer the leakages and consequently the higher the multiplier effect (Clawson and Knetsch, 1966).

A multiplier appropriate for tourism impact analysis must reflect not only the employment and income kept in the system, but also that which leaks from it (McCannell, 1976). Successive rounds of income and spending may be reduced by leakages in the form of payments for imported goods and services. The composite tourist multiplier model developed by Glenn D. Weaver, et al (1978), of the Department of Recreation and Parks Administration, University of Missouri, seems applicable to the present research problem. It involves a nine step analytical procedure that measures and compares the indirect effects of tourist spending. The 
pattern and volume of tourist expenditure is broken down and multiplied by the metropolitan value added elements. The most sensitive part of this model is in the measurement of the leakage element because the amount of money which remains in the metropolitan area to recirculate is primarily governed by the value of the sales to tourists of goods and services produced in the metropolitan area and the value added by the marketing of those outside goods and services bought by tourists (Archer and Owen, 1971). The model uses some elements of the input-output table to derive a composite probability index of spending metropolitan income on locally-produced goods and services.

\section{MONETARY BENEFITS AND COSTS}

As any other industry, tourism brings economic benefits that are vital for economic growth. Dollars spent by tourists on lodging, food and various services can make a significant contribution to the income and employment of the area. However, tourists also place demands on local public services and amenities in the area they visit. At the peak of the tourist season, some communities may find themselves with double or triple their normal population, a situation which engenders both monetary and social costs to the permanent residents. Metropolitan services such as fire, police and sanitation can be strained. Crowded streets, noise and environmental degradation can disrupt the quiet, neighborhood lifestyle which makes the area a desirable 
place to live.

Monetary benefit-cost analysis is a technique used to balance costs against benefits to show the estimated tourist net effects. However, analysts on the same project may differ in their findings because tangible and intangible benefits and costs with the usual quantification problems (Lundberg, 1973) are involved.

\section{Monetary Benefits}

Monetary benefits may be defined as the touristgenerated revenue collected by the metropolitan area. Benefits most commonly associated with tourism are increased incomes and employment for the community. While the metropolitan area collects a small amount of revenue directly from the tourists (through parking meters for example), real estate taxes provide a large portion of the public benefits that can be traced to the tourist business. That is, a major component of monetary benefits attributable to tourists is the property taxes paid by the mercantile establishments that serve them. But only a portion of the taxes paid by these businesses can be considered a metropolitan benefit caused by tourists because these establishments pay local taxes regardless of tourist spending in any given year. These businesses are, in fact, supported to a certain extent by sales to tourists and to the local residents. This makes it difficult for an analyst to decide whether local real estate taxes paid in most cases can be directly attributed 
to tourism, and if so, what percentage. However, if an allocation formula is devised on the basis of percent of sales to tourists and local residents, the actual total taxes paid generally are a matter of public record and can be easily obtained. Another benefit which may accrue from tourism is increased revenues that may be used to provide additional public services. Tourism may also provide a means of diversifying the economic base, which is jarticularly important in areas dominated by one industry.

Skeptics maintain that the low-wage employment needed to serve the tourist industry can be a threat to the local economy. They state that most tourism jobs offer only subsistence wages and hence do not increase the overall wage income of the local area (Young, 1973). Such critics only look at the monetary multiplier and not at the employment multiplier. Because tourism is a labor-intensive service industry, it is a valuable source of employment. It employs large numbers of people and provides a wide range of jobs which extend from unskilled to highly specialized. Though social benefit are perhaps unquantifiable, generally it can be said that tourism widens the employment opportunities for housewives, college sudents, and teenagers who cannot work full time throughout the year. In a sense, tourism helps to put some wealth in the hands of some people who otherwise might not be receiving any. Moreover, any job is better than no job at all when multipliers are considered. For the unemployed, perhaps with self-esteem at low ebb, tourism 
jobs may provide a needed opportunity.

\section{Monetary Costs}

In addition to the above benefits, there are ilso costs associated with tourism in any tourist destination area. The services which the metropolitan area provides to tourists are the same services provided to permanent residents. These include public safety (police and fire protections), sanitation, roads and streets, parks and recreation, sewer and water services. Less obvious but still relevant are the general services of the metropolitan government: administration, advertising, etc. To some extent, the level of these services is higher because of tourists; therefore, a portion of the costs might be rightly attributed to them. But most of these costs are borne by the resident population through property and other forms of taxation and can therefore be seen as metropolitan public costs incurred because of tourists' presence.

\section{Calculating Monetary Benefits and Costs}

With traditional benefit-cost analysis, future income is less highly valued than present income. Calculations of the value of future benefits and costs values must be discounted back to a present worth equivalent, thereby making them comparable, especially when associated with any development project (Clawson and Knetsch, 1966). This research problem is not suitable for traditional benefitcost analysis because the thrust of the research is not 
to estimate the costs-benefits associated with any development project, e.g., water control structures, irrigation ditches, hydroelectric power generators, flood control. etc. Rather, this research problem addresses itself to weighing the benefits from tourist spending in a given year to the costs of providing public services to the tourists.

Since the 1950's, a number of analytical techniques have emerged for measuring fiscal benefits and costs. These techniques include the per capita multiplier method, the case study method and comparable city to proportional valuation methods (Burchell and Listokin, 1980). These methods are mainly used for projection purposes, and as such are not designed for a one period measurement of monetary benefits and costs required in this study.

Data Used in Tourist Impact Studies

The literature review shows that a multiplicity of definitions exist to determine who is a tourist. In 1963, the United Nations gave a much broader definition of a tourist than the ones alluded to in Chapter I (one adopted from the International Union of Official Travel Organizations - I.U.O.T.O.). It defined a tourist as a temporary visitor staying at least twenty four hours in the country, state, or city visited and the purpose of whose journey could be classified as either leisure or business (Peters, 1969). However, definitional problems of a more operational 
or basic level remain. These relate mainly to collection, analysis and interpretation of information in order to develop a measure of tourist economic impact.

No fully accepted, industry-wide organization exists to represent the industry's interests or keep records of its economic performance, especially at the local level. The Travel Industry Association of America (T.I.A.A.), the United States Travel Data Center (U.S.T.D.C.), the Travel Research Association (T.R.A.), and the United States Travel Service (U.S.T.S.) have made some contributions at national and international levels, but they have not been able to provide much information at state or local levels. Their major contribution is in providing basic data on the national and international tourism market. They are also in the process of developing guidelines to assist state, federal, and private data collectors in standardizing definitions and procedures so that data are comparable. They have not been successful in providing information at the state and local levels (Goeke, 1981).

Data published by the Federal Government on consumer spending patterns are not organized in such a way as to make them even marginally useful to the tourist impact analyst. The Federal Government developed and initiated some travelrelated research programs through the Department of Commerce. One of these is the Census of Transportation, whose surveys are conducted quinquennially by the Bureau of Census, another is the study and report of the National 
Tourism Resource Review. Such data are of limited value at the local level because they are available on a broad regional basis only and are divided into components that obscure potentially valuable information for the researcher. Similar problems are encountered by those attempting to use data from the Census of Business to estimate gross retail sales or gross service receipts attributable to tourists. These data are published at five year intervals on state, county and metropolitan bases, but the data are grouped according to product and process similarities, which poses considerable problems. As an example, the Department of Commerce publishes estimates of personal expenditures on a variety of goods and services. One category used is recreation. This grouping includes such items as toys, sporting goods, expenditures on radio and television, admission to amusements, and reading matter. A similar problem arises with the commerce classification of expenditures on hotel and motel accommodations under housing. This significant item in tourist expenditure is thus lost to the researcher (New Hampshire Department of Resources and Economic Development, 1962). From the perspective of Census of Business, businesses are considered essentially as suppliers of goods and services of particular types; the user source of these products is totally disregarded. Hence, the contribution of tourists to the retail sales or the service receipts of a given area cannot be ascertained directly from an examination of the Census of 
Business data.

As a result of these limitations in the utility of federally published data and the above conceptual and pragmatic problems associated with the tourism industry, questionnaires, personal interviews and data collected by the local or state agencies are the only sources of information on tourist expenditures, sales, and receipts. The data most often used are from surveys of tourists and tourist-related businesses.

Surveys of tourists suggest that contacting the subjects while they are traveling in the area should accomplish two objectives. The first is to derive behavioral information, particularly information about spending behavior, for different classes of tourists. The other objective is to obtain figures about total number of tourists of various types. These data are then applied to the type counts to obtain a measure of tourist spending. The general concept involved in this data collection method is that tourists are intercepted according to a statistically-designed sampling plan generally at points of entry or exit to the metropolitan area, region, or state. They are interviewed as well as counted to obtain information about trip purposes, expenditures, etc. They may be asked to maintain a diary to record the details of their travel while in the area. This method will be particularly useful where there is a relatively small number of clearly defined points for crossing the cordon lines or boundaries of the 
area. Tourists will tend to forget many expenditures, especially when asked to consider the entire period spent in the area. They will normally remember better the expenses from the last day than from the earlier days (Weaver, 1978). It has been suggested that a diary format for continual recording of spending is the most accurate method of obtaining this information since it requires minimum recall. Having to record expenses may change a tourist's spending habits, which thus biases the total tourist spending estimates.

Another alternative is to send questionnaires to a random sample of tourists derived either from various registration data or from tourist response to a national magazine advertisement (Robinson, 1976). These types of questionnaires have a higher response rate than the diary method, but a lower response than entry/exit interviews. Also, the time lapse increases the tendency to underestimate actual expenses. The Oregon Department of Transportation used a combination of these data collection methods to derive the estimated 1980 tourist expenditures in Oregon (Oregon Department of Transportation, 1980).

Another data collection method for measuring tourist impact is a survey of tourist-related businesses such as restaurants, gasoline service stations, sourvenir, and gift shops, movie theatres, and sports events. The assumption in this method of data collection is that the business proprietor is an astute observer of his business fatterns 
and is able to make a reliable estimate of the percentage of his business originating from tourists and local residents. But there are some limitations to this method. Business management does not always have adequate knowledge or records to determine the percentage of sales made to local residents as distinguished from tourists. While business surveys can provide useful data for tourist impact measurement, they cannot provide data for a conplete economic impect measurement.

Other data that may be relevant in tourist impact measurement are highway traffic counter records typically collected by state, county, and city traffic and transportation departments. Although this data can provide certain essential inputs for the tourist impact study, measurements of tourist impact based on this source alone suffer from certain problems: the highways and roads are often used by tourists and residents, and data from traffic counters are not normally disaggregated to reflect the actual contribution of the tourism-related portion. For example, traffic counters at cordon lines do not discriminate between cars driven by people on vacation trips and local residents on their way to grocery stores or driving to and from work. None of the data sources thus reviewed is without some limitations, but each has a certain utility. The data utilized has to be amenable to the purpose and locality of the study in question. 


\section{CHAPTER III}

\section{METHODS AND DATA}

As indicated in the previous discussion, most research on the impact of tourism has been done at national and state levels and has dealt either with the assessment of income and employment multiplier effects (Archer and Owen, 1971; Kite and Schultz, 1967; McIntosh, 1973), or with a special project such as effect of tourism-induced hotel developments on urban residential housing. These studies generally present no in-depth analysis of the monetary benefits and costs associated with tourism.

The methodology developed in this study offers an improvement on tourism impact analysis in the sense of specifically measuring tourism's monetary benefits and costs at the city level, with Portland metropolitan area providing the specific example. Though prediction of the income and employment multiplier effects are not the primary goal of the research, they are developed as intermediate inputs in assessing metropolitan monetary benefits.

Two major sets of data were needed to accomplish the research task. The first set includes tourism-induced property tax revenues, business license and gasoline tax revenues, parking and room occupation tax revenues, public amusement-recreation revenues, and indirect property tax revenues from tourism-generated payroll in the metropolitan area. The second set of data includes metropolitan service 
expenditures. Other relevant data needed for the study include: the volume and pattern of tourist spending in the area, number of tourists who visited the area, length of stay, and percent of business transactions attributable to tourists. Data on the percent of goods and services utilized by businesses from outside the metropolitan area, population of the metropolitan area, total property taxes collected during the study period, and the metropolitan gross income are indirectly important. Before elaborating on these data, it is necessary to define who is a tourist, as well as specifically stating the research questions and research hypotheses.

Who is a Tourist?

The definition of a "tourist" is a subject of some controversy in the literature. Different definitions deal with different levels of geographical specificity, as discussed in Chapter I. However, some agreement is clear. Persons going about their normal daily routines such as driving to and from work or the supermarket, while traveling in the strictest sense, are not tourists so far as the literature is concerned (Goeke, 1981). Tourists; for purposes of this study, are defined as anyone traveling into the metropolitan area (South of the Columbia River) for a period of twenty-four hours or more. This definition includes those who come into the metropolitan area for pleasure or business, educational or personal reasons which are not a 
part of their regular routine of activities. This definition excludes those persons entering the metropolitan area with or without a contract to take up an occupation or residence, and students and young persons in boarding schools.

Research Questions and Hypotheses

This study addresses the following research question: Do public expenditures attributable to tourism outweigh the revenue benefits derived from tourism in the metropolitan area, or is the metropolitan taxpayer really subsidizing the tourism industry?

In order to guide the research, two major hypotheses are offered.

1. Tourism in the metropolitan area provides a significant employment creation and income generation possibilities.

2. Tourism creates more benefits than it causes service costs to the metropolitan area.

An additional minor hypothesis is:

Even though many tourism-related jobs are low-paying, they are still useful in providing minority ${ }^{2}$ employment and indirect property tax revenues.

2 Minority population here is used in a general sense and includes all females and a large number of ethnic white and black males. 
DESIGN

An understanding of the per capita cost-revenue method used to test these hypotheses depends upon acceptance of several basic assumptions:

1. Average operating cost per capita provides the best estimate of general operating costs.

2. For most services, the costs of serving permanent residents are not significantly different from the costs of serving tourists.

3. The percent of tourists that visited the metropolitan area and their spending during the study period is typical for the area generally.

The second assumption rests on the concept that most local public expenditures are proportional to the number of people being served. Overall, tourists incur roughly the same costs which a similar number of full-time residents would incur. However, if analyzed in terms of individual services, this assumption may not hold. For instance, overnight tourists do not own homes and property which require police and fire protection. However, the presence of tourists may require increased police and fire protection of both commercial and residential property in the metropolitan area. Despite such variations, it js reasonable to assume that, on the average, tourist and resident public cost per person-day or per tourist-day are approximately equal. With 
the third assumption, critics allege that Oregon tourists spend more in the Portland metropolitan area than in any other Oregon community. Based on data from the Oregon Department of Transportation, Travel Information Section, there is no statistical method at present to verify this statement. Therefore, this study assumes that the percent of Oregon tourists who visited the metropolitan area during the study period is a reasonable approximation of general time and money spent. These assumptions will be discussed further subsequently.

Relating to the above assumptions, the total metropolitan service expenditures was divided by the total person-days (residents and tourists) to derive costs per person-day. Also the total metropolitan tourism-induced revenues were divided by the total tourist-days to derive benefits per person-day. Metropolitan costs per person-day subtracted from metropolitan benefits per tourist-day, yield the net benefit per person-day. However, the income and employment multiplier indices are first developed as intermediate inputs in assessing the monetary benefits and costs.

\section{Field Area and Time Period}

The Portland metropolitan area south of the Columbia River (see figure 1) is the microcosm chosen to develop a methodology for ascertaining the economic impact of tourism. The tourist end destination qualities of Portland have been 


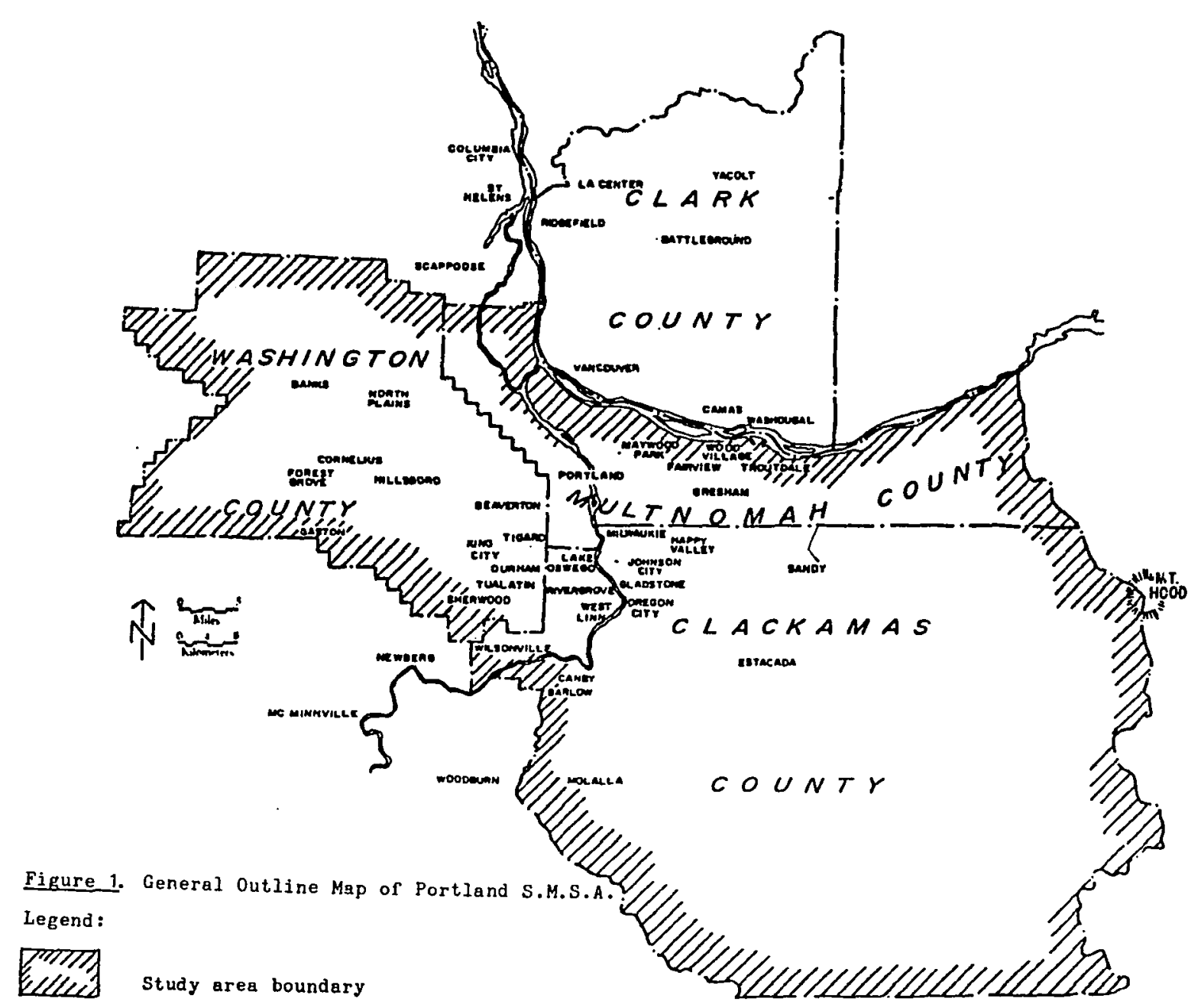

Source of Map: Metro. Service Dietrict Portland, Oregon. 
previously alluded to in Chapter I. Additionally, although Portland does not have natural and recreational attractions such as skiing and coastal beaches, its urban amenities have been successful in attracting the Oregon tourist for a portion of his stay in the state. Therefore, Portland serves as an end destination to some people who want to tour and still remain in an urban environment. Moreover, it is an appropriate size for this type of study: small enough to be manageable, yet large enough to be significant in the context of this type of analysis.

The calendar year, 1980, is the time period covered in this study because pertinent information and data are fairly fresh in the minds of tourism-related business proprietors interviewed. Moreover, in 1980, the Travel Information Section, Oregon Department of Transportation, conducted a survey of Oregon tourists, which provides important secondary data for this research. Lack of comparable data for Clark county has precluded it in the analysis. Moreover, it has a different taxing structure from the other Oregon counties. Thus, for this first analysis, it is reasonable not to work in the context of having to deal with two different revenue structures.

\section{DATA SOURCES AND TYPES}

The data used in this research is mainly of interval level. Both secondary and primary data sources were utilized. 
Secondary Data Sources

The major sources of secondary data used in this study were the 1980 Oregon State Department of Transportation Tourist Survey Results and the 1980-81 Tri-County Property Tax and Assessment Roll Files. These and other secondary data sources are discussed below.

1. In 1980, the Travel Information Section, Oregon Department of Transportation, conducted a road survey of Oregon visitors. The survey asked questions about tourists' vacation planning and itineraries; they were required to fill out a questionnaire relating to their vacation expenditures and pattern of spendings.

Later in the same year, another survey study aimed at measuring the effectiveness of Oregon's tourism promotion program was conducted by the Travel Informtion Section, Oregon Department of Transportation. An advertisement was placed in four national magazines (Redbook, Sunset Magazine, Southern Living, and New Yorker). Readers who responded to the advertisement by returning the reply cards were sent survey questionnaires from the Travel Information Section. The questionnaires asked respondents to indicate Oregon areas they visited, means of travel, and spending pattern while in the state. From these surveys, it was estimated that 13,038,000 travelers visited Oregon in 1980, stayed a collective total of $51,038,398$ days, and spent $\$ 1.4$ billion. These estimates related to automobile and air travelers and did not include visitors who arrived by sea (the overall 
state figures were adjusted before being applied to the Portland metropolitan area). The Portland metropolitan area was visited by 23 percent of Redbook respondents, 39 percent of Southern Living respondents, 35 percent of New Yorker respondents, and 20 percent of Sunset Magazine respondents. Overall, an average of 29 percent of all respondents visited the Portland metropolitan area during their stay in oregon. By applying this percentage (as discussed above) to the number of tourists $(13,038,000 \times 0.29=3,781,020)$, total length of stay $(51,038,398 \times 0.29=14,801,135$ days $)$ and total dollars spent $(\$ 1,140,000,000 \times 0.29=\$ 330,600,000)$, the following es:imates were made. Approximately 3,781,020 tourists visited the Portland metropolitan area in 1980, stayed $14,801,135$ collective days and spent $\$ 330,600,000$.

2. Recently, a study on the "Economic Impact of the 1981 Portland Rose Festival" (Robb, 1981) reported that during the Rose Festival, nineteen ships representing the United States Navy, the Coast Guard, and the Canadian Navy visited Portland for five days. It estimated that "5,000 officers and enlisted personnel from the ships spent $\$ 1$ million" in the metropolitan area during their stay. In 1980, the same number of ships and enlisted men visited Portland during the Rose Festival. 1981 spending was assumed to be approximately equal to 1980 spending after adjustments for deflation were made. Using a deflation 
index of 1.11 "(C.P.I. - J)"3 for Portland (U.S. Department of Labor, Bureau of Labor Statistics, 1981), it was estimated that this group spent $\$ 0.9$ million $(\$ 900,900.90)$ during their five-day stay.

3. In order to assess the full economic impact (direct and indirect) of tourism on the metropolitan area, the monetary benefits and costs attributable to tourism must be analyzed. To facilitate this aspect of the study, the data collection process was extended to incorporate the assessed values and property taxes paid by the 315 touristrelated businesses previously sampled. Since these values and the appropriate taxes are based on fiscal years (July 1 - June 30) rather than on calendar years, this study had to rely on the 1980-81 assessed values and property taxes paid. All other data from the various metropolitan government units were also based on fiscal year 1980-81 figures. The information on assessed values and property taxes was important for this research because these businesses receive significant income from residents and tourists alike. Hence, a portion of business owners' property taxes should be attributed to tourists in the area. The assessed values and property tax levies on the sampled businesses in 1980-81

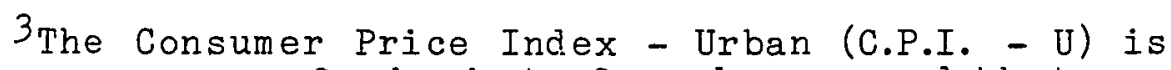
based on a survey of a basket of goods assumed that people purchase in urban areas. Applying the C.P.I. - U of 1.11, $\$ 1$ milition $\div 1.11=\$ 900,900.90$. The 1.11 index means, for example, that an item which sold for $\$ 100$ in 1980 would cost $\$ 111$ in 1981 . 
were obtained by tabulating information from the "Assessment and Taxation Role Files" of three counties (Multnomah, Clackamas and Washington). A weighted mean of assessed values and property tax levies in each business category was used to obtain estimated assessed values and property taxes paid by each type of business. That is, the weighted means in each business category times the number of businesses in each category (as listed by the Contacts Influential) equal the estimated assessed values and property taxes paid. In attempting to derive dollar estimates for these property values and taxes, it was assumed that the mean property values and taxes obtained from the establishments' sample would have remainea constant had coverage been expanded to encompass all tourist-related businesses in the metropolitan area.

This approach was plagued by methodological problems where there was joint occupancy of a lot or building by several businesses. Similar problems were encountered where a business previously sampled was located in a shopping center or mall. In such cases, the County Assessment and Taxation Roll Files indicated single assessed values and property taxes for the building or shopping centers. This made it difficult to determine the property taxes paid by some businesses relevant to the study. The problem was ultimately resolved by personal interviews with the proprietors of the businesses. During the interview phase, proprietors were requested to indicate the amount of rent 
paid per month. The stated monthly rent was multiplied by twelve to obtain estimates of the annual rent paid. The appropriate tax levies were then calculated, taking into account the appropriate "tax rates per thousand dollars" for each district. It was estimated that tourist-related businesses in the metropolitan area collectively paid $\$ 13,626,556.63$ in property taxes during the study year. The sample percentage of gross sales or receipts attributable to tourists in the metropolitan area was applied to derive the amount of property taxes due to tourist spending paid by each category of business. This area will be more fully elaborated in the benefit-cost section of this study.

4. Due to voter approval in November 1978, Multnomah, Clackamas, and Washington counties have "room occupation $\operatorname{tax} " 4$ levies of $5 \%$ in Washington county and $6 \%$ in the other two counties. This tax levy was imposed on all hotel-motel rooms occupied by transients or tourists in the metropolitan area. A total of $\$ 3,689,895.20$ was collected from the tax in 1980-81. The sources for this data were the Multnomah County. Independent Audit Report for the Cities and County 1980-81, Clackamas County Budget Review Records, Accounts Status Report 1980-81, and Washington County Finance

\footnotetext{
4 The room occupation tax is basically used for tourist financing operations and promotion. It goes by many names including bedroom tax, lodger tax, hospitality tax, or resort tax. When collected, a portion of this tax is transferred to the Greater Portland Convention and Visitors Bureau for tourism promotion in the metropolitan area.
} 
Accounts Receivable Report 1980-81.

Another area taxed in Oregon is gasoline. For example, a state tax of eight cents per gallon was imposed on every gallon of gasoline sold at gas pumps in Oregon; Multnomah County imposed an additional three cents per galion tax, and Washington County residents paid one additional cent per gallon in tax. Clackamas County imposed no additional gasoline tax. At the end of the year, the state sends taxes collected back to the counties and cities for road repairs. Since residents and tourists bought gasoline from these stations during the study year, such revenues attributable to tourism would be of some monetary benefit to the metropolitan area. Thus, data from this revenue source were collected. It is important to note that the money sent to the counties and cities at the end of the year came from other sources in addition to fuel tax (sources such as driver license fees, motor vehicle registration fees, and truck weight mile taxes). The State Highway Division, Accounts Section, which manages these funds, estimated (1982) that in 1980-81 fuel taxes accounted for 51.4 percent of all funds returned to cities and counties. Drivers licenses and motor vehicle registrations accounted for 14.3 percent and 34.3 percent, respectively. The amount of revenue from fuel tax was derived by using the 51.4 percent as a weighting measure. Total revenues from both state and county gasoline taxes amounted to $\$ 14,571,146.99$. 
Since the sales of gasoline in the study year were made to both residents of the metropolitan area and to tourists, the formula of percentage of gross sales by the gasoline service stations to tourists and local residents was applied to derive the amount attributable to tourists.

Parking meter and parking garage fees provide yet another source of revenue which tourists contribute to. The amount of fees paid by a motorist depends on the length of use of the parking space. Since both local residents and tourists used these public parking spaces in the study year, data on these user fee revenues were collected and the amount of revenues attributable to tourists was computed. The totai amount of revenues from parking meters and public parking garages was $\$ 4,378,561.84$ in the study year (Tax Supervising and Conservation Commission, Multnomah County 1980-81). To derive the amount attributable to tourism, it was assumed that the percent of these revenues due to tourist presence would be equal to the percent of tourist person-days in the metropolitan area.

5. There were other metropolitan revenues, part of which could be attributed to tourists. One such revenue is license fees collected from tourist-related businesses. The State of Oregon requires all lodging, eating, and drinking establishments to be licensed by the County Health Departments before they can operate, even though they also pay for business licenses in the various cities in which they are located. Hence data were collected on this revenue 
source from the Clackamas County, Washington County

Environmental Health Departments and Multnomah County Health Sanitation Department, "Annual Financial Reports, 1980-81." The percent of gross sales to tourists was again applied to derive the amount due to tourists. In attempting to tally the cost of the various city business licenses, a divergence of rates was discovered. Some cities had organized license revenue according to business types; some cities had flat rates ranging from $\$ 8.50$ - $\$ 40$ per business, while others had adjustable rates depending on number of employees per business. The amount of revenues from this source was collected from each city Business License Division or Finance Department. Where any of these departments had not readily organized such data, reference was made to the listing of businesses, their addresses, and range of employees as shown in the Contacts Influential. Thus, revenue figures were derived in accordance with these various business licensing structures. The total amount from this revenue source was $\$ 332,387.45$. Again the formula of percent of gross sales to tourists was applied to derive tile amount attributable to tourists.

In any year, both tourists and the local residents make use of the public amusement and recreation facilities in the metropolitan area. Hence, managers of the public and quasi-public amusement and recreation facilities were requested to provide estimates of tourists as a percent of their total attendance in 1980. Inasmuch as several of the 
managers had previously conducted studies to ascertain the number of resident and tourist users of their facilities, this phase of the study was accomplished easily. The percent of tourist attendance was used to derive the amount of gross revenues attributable to tourists.

Other secondary data used include 1980 metropolitan population figurss, total property tax revenues for 1980-81, and 1980 metropolitan gross income. The 1980 metropolitan population was needed in the computation of costs of providing services to the local residents per person-day. 1980 census figures showed that there were 1,050,367 persons residing in the metropolitan area (U.S. Department of Commerce, Bureau of the Census, 1981). Data on the total property tax revenues 1980-81 and the 1980 metropolitan gross income were important for estimating the "indirect tourist-generated property tax revenues" 5 in the metropolitan area. The procedure for deriving this figure will be discussed later in the methodology section on indirect monetary benefits.

It is recognized that data on the corporate income taxes paid by the tourist-related businesses in the metropolitan area would have been useful in this investigation. However, according to the Internal Revenue Service, this piece of information is not a matter of public

${ }^{5}$ Indirect tourist-generated property tax revenues here refer to the property taxes paid by metropolitan residents who were employed because of tourist spending. 
record. Thus, data on this revenue source, though important, has been excluded from the analysis.

6. Like any other industry, tourism brings benefits as well as costs to the entire community in which it is a major component of the local economy. The services which the community provides to tourists are the same services provided tc the permanent residents. The funding for these services comes from the operating budgets of the various political units in the area. Normally, the budgeted or projected spending for any political unit in a fiscal year does not always equal the actual costs to all political units in the metropolitan area in providing services to its resident population and tourists alike. It is thus assumed to be most reasonable to consider total expenditures rather than projected spendings in the study period.

According to the Oregon Revised Statutes, Chapter 294, each political unit in the state is required to file an audit report at the end of the year with the Audit Division, Secretary of State's Office in Salem. From this source, data on the total expenditures for 1980-81 for all political units in the metropolitan area were collected. In addition to the secondary data sources listed above, there are other relevant data which were collected through use of a survey.

Primary Data Sources and Method of Collection

Since the tourism industry is extensively fragmented, several means were employed in gathering the data needed to 
measure its impact on the pattern of economic activity in Portland, as detailed below.

1. A telephone survey of a randomly selected sample of tourist-related business proprietors in the metropolitan area was conducted. It was practically impossible to survey all the tourist-related business proprietors in the metropolitan area, considering the diversified nature of the industry. However, in order to ensure an adequate coverage of all levels of tourist-related businesses, a strategy was adopted: the lower the number of businesses in each business category, the higher the percentage sampled; likewise, the higher the number of businesses in each business category, the lower the percentage sampled.

To draw the samples, a table of random numbers was consulted in order to select the beginning point for identifying the sample business proprietors. 6 Before the survey, introductory letters were sent to the proprietors of the businesses to be surveyed. The letters explained the intent of the research and sought their participation in the research. The letter also assured the proprietors of complete confidentiality of all information given. Copies of these letters were also sent to the Portland Chamber of Commerce, the Greater Portland Convention and Visitors Bureau, and the Portland Rose Festival Association.

${ }^{6} \mathrm{~A}$ list of these businesses was obtained from Contacts Influential, a Commerce and Industry Directory that lists businesses by Standard Industrial Classification code. 
Follow up contacts were made by telephone. A total of three hundred and fifteen businesses were covered in the survey. During the interview, the proprietors were asked to estimate the percentage of their 1980 sales or receipts attributable to tourists in the metropolitan area. This percentage was then subtractea from 100 to give, for each proprietor, an estimated percent of gross sales originating from local residents. Proprietors were also asked to estimate the percentage of their goods and services originating from within or outside the metropolitan area following the above procedure. This information was necessary in order to estimate the amount of tourist spending that leaves the metropolitan area in form of leakages. The proprietors were also asked to indicate in terms of person-weeks, the number and type (minority or nonminority) of people they employed. This information was important mainly in establishing the relative percentage of minorities and nonminorities employed by the tourist-related businesses. Appendices $A$ and $B$ show examples of the questionnaires used in the survey.

2. Also important for this research was the data on the amount of money bartenders, waitresses and bus persons claimed as tips during a typical working day. Originally, a survey questionnaire was designed to interview them for this information. However, too many subjects declined to participate in the study because the information on tips was regarded as highly sensitive. Fortunately, a study on hotel 
and motel, tipped employee hourly earnings and tips as a percent of earnings for most cities in the United States, including Portland, was presented by Kelleher in 1976.

Hence, instead of interviewing the bartenders, bus persons and waitresses, a personal interview of sampled hotel and eating-drinking establishments' managers was conducted. In the survey they were requested to indicate whether there had been any change in tip rate between 1975 and 1980. If the tip rate had remained the same or changed, the managers were requested to briefly give their reasons. This information was needed to confirm or refute the assertion that tourist related jobs are at minimum wage levels and that most of the workers ultimately appear on Welfare rolls (Judd, 1979). Sixty hotel and eating-drinking establishments' managers were interviewed. And a sample of the questionnaire used in this survey is shown in Appendix $C$. 
CHAPTER IV

THE MULTIPLIER AND MONETARY BENEFIT-COST MODELS

All the datadiscussed in the last chapter were used where applicable, to measure the economic impact of tourism in the Portland metropolitan area as shown in the following models. Three methodological sequences were carried out in this study. The first two are models to compute income and employment multipliers. These models helped in the development of intermediate inputs applied in executing the monetary benefit model. But because of the direct linkage of the benefit model to the income and employment multiplier effects, monetary benefits are first elaborated in the following discussion. Figure 2 provides a graphic representation of the research models.

The execution of these models involves a set of submodels which first have to be computed. Each part of the submodels involves sets of assumptions and parameters that must be estimated. These assumptions and the argument for the estimation procedure will be taken up during the elaboration of the submodels. Some of the assumptions have inherent problems, and these will be further discussed in Chapter VII. 


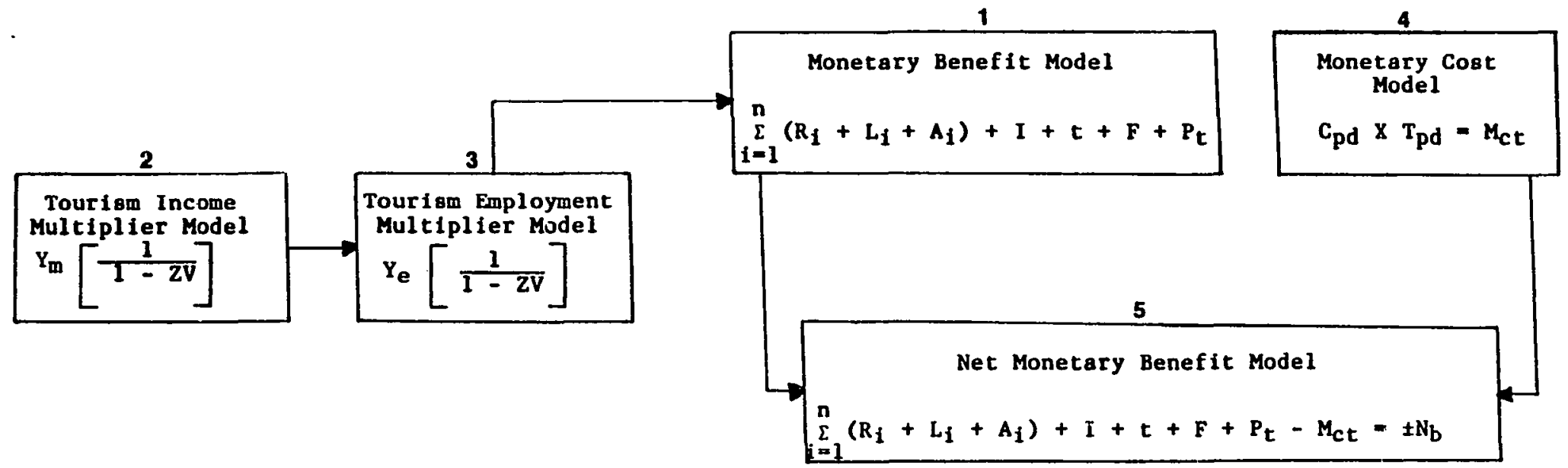

Eigure 2. General Outline of Research Models. 
BENEFITS

This section of the methodology describes the techniques and procedures used to measure the monetary benefits of tourism to the Portland metropolitan area. As discussed earlier, there is no doubt that the Portland metropolitan area has benefited from an expanded tax base which could be attributed to tourist spendings. There are other benefits which will also be discussed. Thus, there are two types of monetary benefits (direct and indirect) derivable from tourism in the metropolitan area.

\section{Direct Monetary Benefits}

Monetary benefits here may be defined as the touristgenerated incomes in the form of taxes and other revenues from businesses attributable to tourism that are collected by metropolitan governments. Metropolitan governments collect small amounts of revenue directly from tourists through parking fees. However, most of the metropolitan benefits that can be attributed to tourism are provided by real estate taxes paid by mercantile establishments. These establishments pay local property taxes regardless of tourist spending in a year. However, because these businesses are, in fact, supported to a certain extent by sales to tourists and local residents, only a portion of the taxes paid by these businesses can be considered a metropolitan benefit caused by tourism. In order to apportion these property taxes, the research relied on the assumption that the 
portion of an establishment's property tax bill was equal to the percentage of its total sales which were made to tourists.

Other direct metropolitan benefits associated with tourism are hotel-motel room taxes, fuel taxes, business license fees and other fees paid by tourists at public amusement and recreation estaishments. Also, since these businesses serve both tourists and residents alike, the formula of percentage of their gross sales to tourists was used to derive the amounts of revenues due to tourists' presence or spending. With public amusement and recreation establishments, the percentage of their local and tourist attendance in the study year was used to determine the amount of revenues attributable to tourists.

\section{Indirect Monetary Benefits}

In addition to the direct monetary benefits, there are also indirect benefits from tourist spending. As indicated earlier, tourism provides jobs in the metropolitan area, both directly and indirectly. Both those employed directly and indirectly from tourist spendings own or rent housesapartments in the metropolitan area. These properties have values and hence, property taxes are collected by the metropolitan government. Revenue from these sources can be described as the indirect property tax revenues by touristgenerated employment in the metropolitan area.

These benefits are estimated by the following 
calculation:

$\frac{\text { Metropolitan Property Tax Receipts }}{\text { Metropolitan Adjusted Gross Income }}$ Tourism-

Generated Payroll = Indirect Property Taxes paid by Tourism-Generated Employment.

\section{Calculating Monetary Benefits}

The method developed in this study to measure the metropolitan benefits due to tourists in the study year involves computation of average revenues per tourist-day. This is the amount of monetary benefits derived by the metropolitan area from a tourist per day. The assumption here is that the derivation of average revenues per touristday is the best estimate of monetary benefits attributable to tourism in the metropolitan area. The monetary benefits per tourist-day can be expressed with the formula:

$$
\mathrm{B}_{\mathrm{pd}}=\frac{\sum_{i=1}^{\mathrm{n}}\left(\mathrm{R}_{i}+\mathrm{L}_{i}+\mathrm{A}_{i}\right)+I+t+F+P_{t}}{\mathrm{~T}_{\mathrm{pd}}}
$$

$$
\begin{aligned}
& \text { where } \mathrm{B}_{\mathrm{pd}} \text { = Average revenues per tourist-day. } \\
& R_{i}=\text { Tourist-generated property tax revenues iy } \\
& \text { business category. } \\
& \mathrm{L}_{\mathrm{i}} \quad \text { = Tourist-generated business license revenues. } \\
& \text { I = Indirect property tax revenues. } \\
& t=\text { Room occupation tax revenues. } \\
& A_{i}=\text { Tourist-generated amusement and recreation } \\
& \text { revenues. } \\
& F \quad=\text { Tourist-generated fuel tax revenues. }
\end{aligned}
$$




$$
\begin{aligned}
& \mathrm{P}_{t}=\text { Tourist-generated parking revenues. } \\
& \mathrm{T}_{\text {pd }}=\text { Total tourist person-days. }
\end{aligned}
$$

1. The tourist-generated property tax revenue by business category was derived by applying the percent of the business proprietors' gross sales to tourists (as obtained from a survey of business proprietors) to the total property taxes paid. That is,

$$
r_{i}+t_{i}=s_{i}
$$

where $s_{i}=$ total gross sales by business category.

$r_{i}=$ sales to local residents.

$t_{i}=$ sales to tourists.

then $t_{i}=$ percent sales to tourists in the area.

The ratio of $\frac{t_{i}}{s_{i}}$ (percentage) was used to derive the amount

of property tax attributable to tourism in each business

category: $\sum_{i=1}^{n} Q_{i}\left[\frac{t_{i}}{s_{i}}\right]=\begin{aligned} & \text { total tourist-generated } \\ & \text { property tax revenues }\end{aligned}$

where $Q_{i}=$ metropolitan property tax revenues by business category. The product of the above calculation yielded the tourist-generated property tax revenues by business categories.

2. For room occupation tax, fuel tax, public amusement and recreation facilities, and business license revenues, the percent of the business gross sales to tourists or attendance by tourists was applied to derive the amount of revenues attributable to tourism (formula $1 \mathrm{~b}$ ). 3. With the tourist-generated revenues from public 
parking spaces, the following computation procedure was performed: The total metropolitan person-days in the study year was determined by summing the tourist and resident person-days. The result was the total person-days in 1980 . Then, dividing the tourist person-days by the total persondays in the metropolitan area, and later multiplying that ratio with the total parking revenues, resulted in an estimate of tourist-generated parking revenues in the metropolitan area. The above procedure could be represented by the formula:

$$
\mathrm{T}_{\mathrm{pd}}+\mathrm{R}_{\mathrm{pd}}=\mathrm{TA} \mathrm{pd}
$$

where $\mathrm{T}_{\mathrm{pd}}=$ total tourist person-days.

$$
\begin{aligned}
& \mathrm{R}_{\mathrm{pd}}=\text { Resident person-days. } \\
& \mathrm{TA}_{\mathrm{pd}}=\text { total annual person-days. } 7
\end{aligned}
$$

Then $\left[\frac{T_{p d}}{T_{p d}}\right] P=P_{t}$

where $\mathrm{P} \quad$ = total parking revenues.

$P_{t} \quad$ tourism-generated parking revenues.

The logic and assumptions pertinent to the above computation procedure were that in a given year, both residents and tourists made use of those parking spaces and paid fees according to the length of use. Hence, such revenues collected should be attributable to both residents and tourists to the metropolitan area during the study period.

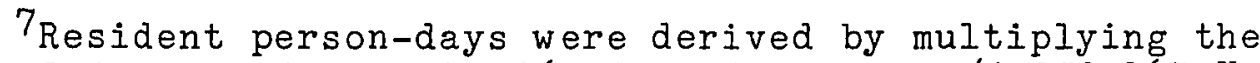
metropolitan population by 365 days in a year $(1,050,367 \mathrm{X}$ $365=383,383,955$ person-days). 
It would have been most appropriate to determine the exact amount of resident or tourist dollars paid into this revenue source. This could be done by surveying the residents and tourists in the metropolitan area to find out how many days in a week they use the parking spaces and for how long. But data of such precision does not currently exist. Since total person-days (residents and tourists) and spending accounted for the total parking revenues collected, the percentage of resident or tourist person-days was assumed comparable to the amount of parking revenues attributable to residents or tourists.

4. To derive the tourist-generated indirect property tax revenues, the following analytical procedures were followed: The tourist-generated employment (direct and indirect) that remained in the metropolitan area must be determined by applying the employment multiplier model. To convert the jobs into monetary terms, reference was made to a publication by the State of Oregon Employment Division -- Oregon Covered Employment and Payrolls by Industry and County 1979. This was used to derive annual earnings per employee in the various business categories covered in the study. Since Clackamas, Multnomah and Washington Counties are representative parts of the State, it appeared reasonable to use the state average employment and payroll figures in the analysis. Thus, to determine the annual payroll per employee in 1979, the total annual payroll by business category in 1979 was divided with the average monthly 
employment. Then to derive the 1980 annual payroll per employee, the 1979 payroll per employee was adjusted with the percent increase in payroll between 1979 and 1980 (estimate from the Research and Statistics Section, State of Oregon Employment Division). To estimate the total employee earnings in the business categories covered, the annual payroll per employee by type of business was multiplied by the number of direct tourist-generated jobs that remained in the metropolitan area by business category:

$$
\sum_{i=1}^{n} Y_{i} E_{i}=\underset{\text { Total direct tourist-generated employee }}{\text { earnings }}
$$

where $Y_{i}=$ Annual payroll per employee by business category.

$E_{i}=$ Direct tourist-generated employment that remained in the metropolitan area.

As indicated earlier, economic benefits due to tourist spending does not stop at the merchants' cash registers. Rather, the benefits, e.g., employment, are multiplied as income derived from tourist-generated receipts are circulated in the metropolitan area through a sequence of spending. Thus, the indirect jobs due to tourist spending, as will be determined in the employment multiplier model, might exist in any of the various sectors that supplied goods and services to the tourist-related businesses covered in the study. These jobs may be skilled or unskilled; however, without specific knowledge of the manpower levels involved in these transactions with the appropriate pay 
scales, the research relied on the federal minimum wage level to gauge the amount of earnings. This estimate was based on a forty-hour work week for twelve months of the year. The total indirect employment earnings were determined by using the annual earnings per employee to multiply the number of indirect tourist-generated jobs.

Having derived the tourism-generated payroll in the metropolitan area, it was then necessary to analyze the relationship between income and property taxes by computing an average metropolitan property tax ratio. This was done by dividing the total metropolitan property tax revenues by metropolitan adjusted gross income. 8 Multiplying this ratio by the tourist-generated payroll in the area, an estimate of the property taxes paid by these residents was derived. The above operation can be represented by the formula:

$$
X\left[\begin{array}{l}
R_{t} \\
\bar{Y}
\end{array}\right]=I
$$

where $X \quad=$ Tourist-generated payroll in the metropolitan area.

$R_{t}=$ Total metropolitan property tax revenues.

$\mathrm{Y} \quad$ = Metropolitan adjusted gross income.

I = Indirect metropolitan property tax revenues from tourist-generated employment.

The monetary benefits were summed and later divided by the total tourist person-days in the metropolitan area

${ }^{8}$ The 1979 metropolitan gross income was adjusted with an inflation index of 1.133. That is, between 1979 and 1980, there was a $13.3 \%$ average increase in the inflation rate. 
The result was an average revenue per tourist person-day in the area during the study period. However, the indirect metropolitan property tax revenues from tourist-generated employment as shown on the above submodel, could not be derived without first computing the income and employment multiplier effects.

Income Multiplier Model

The model applied here is a composite tourist multiplier model, which is capable of measuring the direct and indirect impacts of tourists' spending on the metropolitan economy (Weaver et al, 1978). It also measures the leakage elements. The model can be expressed as:

$$
Y_{m}\left[\frac{1}{1-Z V}\right]=\text { Tourist Income Multiplier }
$$

$$
\begin{aligned}
\text { where } \mathrm{Y}_{\mathrm{m}}= & \begin{array}{l}
\text { Percent of tourist spending that directly } \\
\text { increased metropolitan income. }
\end{array} \\
\mathrm{Z}= & \begin{array}{l}
\text { Percent of metropolitan income } \\
\text { spent in the metropolitan area. }
\end{array} \\
\mathrm{V}= & \begin{array}{l}
\text { Percent of metropolitan goods and services } \\
\text { produced locally and sold locally. }
\end{array}
\end{aligned}
$$

There are nine steps involved in the execution of the above

${ }^{9}$ Some multiplier models do have the unit 1 attached to the above formula; $1+Y_{m}\left[\frac{1}{1-Z V}\right]$, (Archer and Owen, 1971), while some do not e.g., $Y_{m}\left[\frac{1}{1-Z V}\right]$, (Clawson and Knetsch, 1966; Weaver et al, 1968). Since the composite tourist multiplier model developed by Glenn D. Weaver et. al, is utilized in this study, the later formula is applied. 
income multiplier model. According to Weaver et al, (1978), the peculiarity of this model is that each one of these steps fills a certain important part of the overall multiplier model. In the early steps, the direct impact of tourist spending is determined; and the later steps deal with the derivation of parameters to compute the indirect effects. Once the indirect effects are computed, the total impact (direct and indirect) of tourist spending is derived by summing the direct and indirect effects as shown in the following analytical procedures.

\section{Step 1 .}

This step involved the determination of pattern and volume of tourist expenditures in the metropolitan area. This is necessary because the income which accrues to the metropolitan residents due to tourism depends first on the amount of tourist spending. Hence, the more money each tourist spends in the metropolitan area and the more tourists that visit, the higher the increase in local incomes. Secondly, the amount of metropolitan income depends on the pattern of tourist expenditures. For example, gasoline service stations' sales result in less locally-generated income per dollar of expenditures by tourists than will sales from lodging estahlishments (Classon and Knetsch, 1966) because gasoline service stations' sales are made up of supplies from wholesale or other sources outside the metropolitan area, while lodging sales are mainly in the form of labor and other services readily available in the 
metropolitan area. The pattern and volume of tourist expenditures can be determined by a survey of tourists while in the study area or a survey of businesses or agencies responsible for tourism promotion in the area, where such survey and tourist expenditure estimates have been carried out similarly to the one done by the Oregon Department of Transportation. The pattern of tourist expenditures were expressed in proportions or percentages according to touristrelated businesses. These percentages were then multiplied by the estimated total tourist expenditures in the area. The result was the volume of tourist expenditure by category of tourist-related business.

Step 2 .

This required estimation of the percent of tourist expenditure that remained in the metropolitan area. For example, if the local restaurants were able to purchase food from farmers in the metropolitan area, much of the tourist spending in that category would accrue as local income. The data used in this regard were extracted from the survey of sampled tourist-related business proprietors. They each estimated the percent of their supply of goods and services which were from outside the metropolitan area. When such percentage was given it was subtracted from one hundred percent to obtain the percent of their supply of goods and services that accrued from within the metropolitan area. The operation at this stage could be expressed as follows: 


$$
\sum_{i=1}^{n}(100 \%)-X_{i}=K_{i}
$$

where $X_{i} \quad=$ Percent of the business supply of goods and services that were from outside the metropolitan area.

$$
\begin{aligned}
\mathrm{K}_{\mathrm{i}}= & \text { Percent of the business supply of goods and } \\
& \text { services that were from within the metropolitan } \\
& \text { area. }
\end{aligned}
$$

A portion of the tourist spending was used to pay for goods and services from outside the metropolitan area. The amount used to pay for these imports leaked out of the metropolitan economy; the remainder remained in the metropolitan area as income. To derive the dollar value for each category of business, the percent of the business supply of goods and services from within the metropolitan area was used to multiply the amount of tourist spending by business category. When summed for all business categories, the result was the total tourist expenditure that remained in the metropolitan area as income. This was the direct impact of tourist spending in the area.

Step 3 .

This step called for a determination of the percent of tourist spending that directly increased metropolitan income. This was a weighted mean of all tourist sectors or tourist-related business categories. The weights were the percentage of tourist expenditure pattern and the percent of tourist expenditure that remains in the metropolitan area as income (see steps 1 and 2). This could be expressed as: 


$$
Y_{m}=\sum_{i=1}^{n} Q_{i} K_{i}
$$

where $\mathrm{Y}_{\mathrm{m}} \quad=$ Percent of tourist spending that directly increased metropolitan income.

$Q_{i}=$ Pattern of tourist spending.

$\mathrm{K}_{\mathrm{i}}=$ Percent of tourist expenditure that remains in the metropolitan area as income.

It was at this stage that the first set of data needed to execute the multiplier model was determined (see formula 2). As shown above, the multiplication of the pattern of tourist spending with the percent of tourist spending that remained in the metropolitan area as income provided an adjustment factor to reflect the metropolitan economic structure.

Step 4.

This step required an estimation of the percent of metropolitan income that was spent in the metropolitan area. These data were not available from the Oregon State Economic and Business Research Division as expected and thus had to be calculated. In order to obtain these estimates, the Oregon State input-output table was used.

In this step, with reference to the input-output table, the total amount of money spent on personal consumption was divided by the total final domestic demand. The result was then multiplied by one hundred to derive the percent or" local income spent in the state of oregon. The assumptions pertinent to this approach will be stated after the next step, since both steps utilized the same data 
source.

Step 5 .

In Step 5 the following procedure was followed: all the state import spendings as shown in the input-output table were summed and then divided by the total final domestic demand. The result was multiplied by one hundred to derive the percent of goods and services sold within the state that were produced outside the state. Then this percent due to imports was subtracted from one hundred percent to derive the percent of goods and services produced locally and sold locally.

In using the state input-output table to make the above estimates, the following assumptions were made:

(a) The production processes were invariant among regions of the state, including metropolitan Portland.

(b) Industry mixes within sectors in the state were similar to those in the Portland metropolitan area.

(c) The percent of sales to final demand sectors contained in the state table was the same in the metropolitan area for each industrial sector.

These assumptions might be weak because the production processes and industry mixes in some rural and agricultural counties in the State might not be the same as in Clackamas, Multnomah, and Washington Counties. But having provided for the adjustment factor in step 3 , and since there is no input-output study for the metropolitan area, the approach utilized in the derivation of the above indices seems 
reasonable. With all the above estimates (Weaver et al., 1978), it was not necessary to trace out each round of spending to derive the total metropolitan income created because enough information had been collected to determine the income multiplier.

Steps 6-9 involved the execution of the multiplier formula (see formula 2). Step 6.

This step required the computation of a composite probability index of metropolitan income spending on locally produced goods and services, or the marginal propensity to spend metropolitan income on locally produced goods and services. This index was derived by multiplying the percent estimated in Step 4 with the percent estimated in Step 5. Step 7.

In Step 7, the percent calculated in step 6 was subtracted from one (probability of spending on non-locally produced goods and services). The result was then divided into one to derive a local multiplier. Step 8.

In Step 8, the local multiplier derived in step 7 was used to multiply the percent calculated in step 3 (the percent of total expenditure that directly increased local incomes). The result was the tourism income multiplier. Step 9.

This step called for the determination of the total increase in metropolitan income due to tourist spending in 
the study year. Total tourist spending was multiplied by the income multiplier index. The result was the indirect income created in the metropolitan area due to tourist spending. To derive the total income created (directly and indirectly), the amount of tourist spending that remained in the metropolitan area as income was added to the indirect income thus created.

Employment Multiplier Model

The employment multiplier model followed the same format utilized in the last model, except that the dollar values used in the income multiplier model had to be converted to employment. More elaboration of this will be presented in the next chapter. Nonetheless, the two models are the same. The tourism employment multiplier can be expressed with the formula:

$$
\mathrm{Y}_{e}\left[\frac{1}{1-Z V}\right]=\text { Tourism Employment Multiplier }
$$

where $\mathrm{Y}_{\mathrm{e}}=$ Percent of tourist expenditure that directly increased metropolitan employment.

$\mathrm{Z} \quad=$ Percent of metropolitan income spent in the metropolitan area.

$\mathrm{V}=$ Percent of metropolitan goods and services produced locally and sold locally.

\section{MONETARY COSTS}

In addition to the tourist-generated benefits discussed above, the metropolitan area incurs some costs in 
providing services to tourists while they are in the area. Hence, a procedure is needed to determine the metropolitan expenditures for providing services to tourists. The services which the metropolitan governments provide to the tourists are the same services provided to the metropolitan residents. These include public safety (fire and police protection), sanitation, road and street repairs, parks and recreation, sewer and water service. The level and cost of these services are higher because tourists are in the area. Hence, a portion of these services costs can rightly be attributed to the tourists. However, these costs are borne by the metropolitan resident population through property and other forms of taxation, and hence, can be considered to be metropolitan public costs due to the presence of tourists. But tourists pay directly for sone services. Parking is one such example. However, fees collected directly from tourists do not cover the total costs of services provided; the percent they actually pay must be calculated.

The method developed in this research to gauge the metropolitan service costs due to tourism involves estimation of average costs per person-day. It is important to note that public schools and metropolitan transportation district costs are not included in this analysis since education and public transportation are services which tourist-generated taxes support, but which tourists do not use. Hence, only nonpublic transportation and nonschool metropolitan expenditures are attributed to the total 
combined resident and tourist person-days in the study year.

Calculating Tourist Monetary Costs

Calculation of costs per tourist-day was performed as follows:

1. Total 1980 tourist person-days were derived earlier. To provide a common measure for tourists and metropolitan residents, the resident population was also translated into person-days (by multiplying the metropolitan population by 365 days). Person-days for tourists and residents were then summed to derive an estimate for the study period.

2. To derive the costs of providing metropolitan services to residents and tourists alike, the following procedure was adopted: First, all person-days in the metropolitan area were summed (see formula 1c). Second, the metropolitan governments' expenditures in the study period were summed. Total metropolitan expenditures were divided by total annual person-days. The result was the metropolitan costs of providing services per person-day. This procedure can be represented by the formula:

$$
\frac{\sum_{i=1}^{n} E_{x i}}{T_{p} p d}=C_{p d}
$$

where $\mathrm{E}_{\mathrm{xi}}$ = Different metropolitan operating expenditures.

$\mathrm{TA}_{\mathrm{pd}}=$ Total annual person-days.

$\mathrm{C}_{\mathrm{pd}}=$ Cost per person-day.

3. The cost per person-day was then used to identify the 
total monetary costs of providing services to tourists. This was accomplished by multiplying the service cost per person-day by the total tourist days. The result was the total metropolitan costs of providing services to tourists in the study year as indicated in the formula:

$$
\begin{aligned}
& \mathrm{C}_{\mathrm{pd}} \mathrm{X} \mathrm{T}_{\mathrm{pd}}=\mathrm{M}_{\mathrm{ct}} \\
& \text { where } \mathrm{C}_{\mathrm{pd}}=\text { Costs per person-day. } \\
& \mathrm{T}_{\text {pd }}=\underset{\text { Total tourist person-days in the metropolitan }}{\text { area. }} \\
& M_{c t}=\text { Total metropolitan costs for providing services } \\
& \text { to tourists. }
\end{aligned}
$$
in a given year, metropolitan average operating costs per capita provide the best estimate of operating costs. Also, for most services, the costs of serving the metropolitan residents are not significantly different from the costs of serving tourists. This assumption as indicated earlier, rests on the concept that most local public expenditures are proportional to the number of people being served. Thus, tourists generally incurred approximately the same total costs which a similar number of metropolitan residents would have incurred in 1980. If analyzed for individual services, this assuption may not hold. For example, overnight tourists in 1980 did rot own homes and property which require police and fire protection, but the presence of tourists in the metropolitan area might have required increased police and fire protection of both commercial and residential property. Apart from such individual 
variations, it is reasonable to assume that on the average, a tourist and a resident service costs per person-day are approximately equal.

Weighing Monetary Benefits Against Costs

To compare monetary benefits witn monetary costs, the following procedure was followed: All the monetary benefits as computed above were summed. The result was total tourism-generated revenues in the metropolitan area. The total monetary costs due to tourism were then subtracted from the total metropolitan revenues from tourism as shown in the formula:

$$
\begin{aligned}
& \sum_{i=1}^{n}\left(R_{i}+L_{i}+A_{i}\right)+I+t+F+P_{t}-M_{c t}= \pm N_{b} \\
& \text { i.e. net monetary benefit. }
\end{aligned}
$$

The result was a net monetary benefit from tourism in the study year. As indicated in the above formula, the net monetary benefit may be positive or negative, depending on whether or not service costs outweigh monetary benefits. 


\section{CHAPTER V}

\section{ANALYSIS OF THE DATA}

In view of the theory and evidence provided in the previous chapters, this chapter is a direct application of the data set to the method provided in this research. The income and employment multiplier indices are first computed to develop some intermediate inputs used in the monetary benefit model.

\section{RESEARCH MODEL COMPUTATIONS}

\section{Income Multiplier}

As indicated in the last chapter, the "Composite Tourist Income Multiplier" applied in this research can be expressed as shown in formula (2). Nine steps were involved in the execution of the model:

Step 1.

As indicated in Table I, this step called for the determination of pattern and volume of tourist spending in the metropolitan area. 
TABLE I

VOLUME AND PATTERN OF TOURIST SPENDING

Business Category $\quad \begin{gathered}\% \text { of Total } \\ \$ \text { Spent Total Dollar Spent }\end{gathered}$

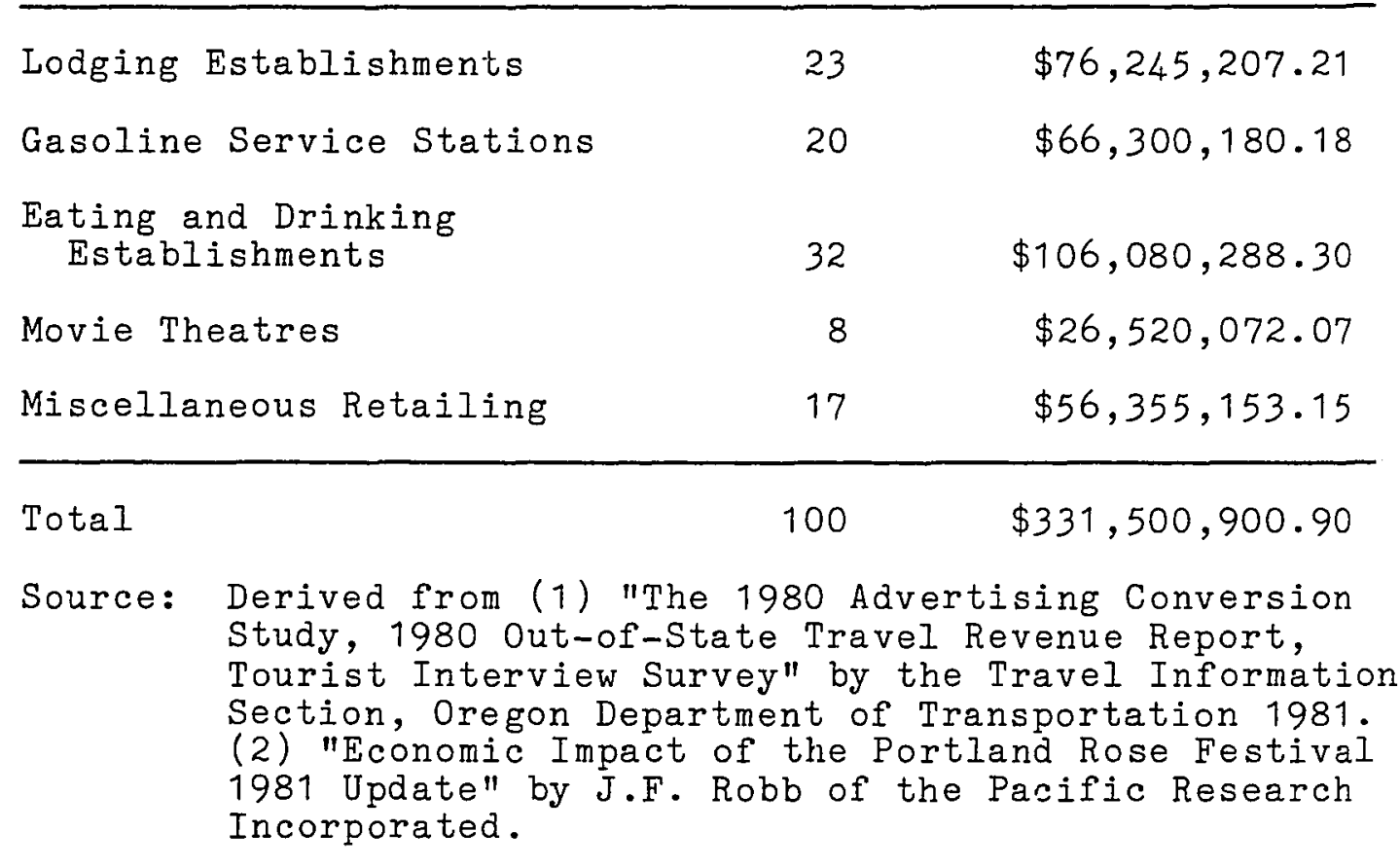

The dollar values in column three of Table I for each

business category were obtained by multiplying the tourist spending in the metropolitan area $(\$ 331,500,900.90)$ by the percent of tourist spending in each business category. Illustrating with lodging establishments: $\$ 331,500,900.90 \mathrm{x}$ $23 \%=\$ 76,245,207.21$.

Step 2.

This required estimation of the percent of tourist expenditures that remained in the metropolitan area. The percentages as shown in Table II were obtained from interviews of sampled tourist-related business proprietors in the metropolitan area. 
TABLE II

PERCENT OF TOURIST EXPENDITURE THAT REMAINS

IN METROPOLITAN AREA AS INCOME

Business Category Percentages Amount ( $\$$ )

\begin{tabular}{lcc}
\hline Lodging Establishments & 81 & $\$ 61,758,617.84$ \\
Gasoline Service Stations & 32 & $\$ 21,216,057.66$ \\
F- ung and Drinking & & \\
Establishments & 72 & $\$ 76,377,807.58$ \\
Movie Theatres & 15 & $\$ 3,978,010.81$ \\
Miscellaneous Retailing & 26 & $\$ 14,652,339.82$ \\
\hline
\end{tabular}

Total

$\$ 177,982,833.71$

Source: Telephone Survey of Sampled Tourist-Related Business Proprietors.

To derive the dollar values due to these percentages, reference was made to the pattern and volume of tourist spending in Table I. For example, with eating and drinking establishments, the percent of tourist expenditure that remained in the metropolitan area was $72 \%$, and the amount of spending in that category was $\$ 106,080,288.30$. Multiplying the spending tigure by column 2 yielded column 3 , the amount of tourist expenditure remaining as income: $\$ 106,080,288.30 \mathrm{X}$ $72 \%=\$ 76,377,807.52$. This was the direct effect of tourist spending in the metropolitan area.

Step 3.

This step called for derivation of the percent of tourist spending that directly increased local income. As indicated in the last chapter, this derivation was a weighted 
mean of all tourist sectors, where the weights were the percentage of tourist expenditure pattern as shown in Table II. The percent of tourist spending in each sector, when multiplied by the percent of tourist expenditure that remained in the metropolitan area, gave an estimate of the tourist spending that directly increased metropolitan income by business category. These were summed to derive the total tourist spending that directly increased metropolitan income (see formula $2 \mathrm{~b}$ ). The computations were performed as follows:

$\begin{array}{lrl}\text { Lodging Establishments } & 23 \% \times 81 \%=19 \% \\ \text { Gasoline Service Stations } & 20 \% \times 32 \%=6 \% \\ \text { Eating and Drinking } & \\ \quad \text { Establishments } & 32 \% \times 72 \%=23 \% \\ \text { Movie Theatres } & 8 \% \times 15 \%=1 \% \\ \text { Miscellaneous Retailing } & 17 \% \times 26 \%=4 \%\end{array}$

Total $53 \%$

The figures used in the above computations were from Tables I and II. They provided some adjustment factor in the model. Step 4.

This step required an estimation of the percent of metropolitan income that was spent in the metropolitan area. As indicated in Chapter IV, this percentage was derived from the State input-output table (Watson and Allen, 1965), which indicated that $\$ 4,250,000$ was spent for personal consumption and that final domestic demand amounted to $\$ 6,450,000$. Total personal consumption divided by total 
domestic final demand equaled percent of local income spent in the state of Oregon: $\frac{\$ 4,250,000}{\$ 6,450,000} \times \frac{100}{1}=66 \%$

The assumptions pertinent to steps 4 and 5 were stated in Chapter IV.

Step 5 .

In step 5, using the input-output table, the following procedure was followed to derive the percent of local goods and services produced locally: All the state import spendings were summed, then divided by the total final domestic demand.

where import spending $=\$ 1,365,000$

final domestic demand $=\$ 6,450,000$

i.e., $\frac{\$ 1,365,000}{\$ 6,450,000} \times \frac{100}{1}=21 \%$

The percent due to imports, when subtracted from one hundred percent, equaled the percent of goods and services produced locally and sold locally: $100 \%-21 \%=79 \%$.

Step 6.

This step required the computation of a composite probability index of metropolitan income spending on locally-produced goods and services. This percent was derived by multiplying the percent estimated in step 4 by the percent estimated in step 5. That is, $66 \% \times 79 \%=52 \%$. Step 7.

In step 7, the percent calculated in step 6 was subtracted from one hundred (probability of spending on 
nonlocally produced goods and services). The result was then divided into one: $100 \%-52 \%=48 \%$.

$$
\frac{1}{48 \%} \text { or } \frac{1}{.48}=2.08
$$

This value was the local multiplier.

Step 8.

In step 8, the local multiplier derived above was used to multiply the percent calculated in step 3 to derive the tourism income multiplier: $53 \% \times 2.08=1.1024$. With reference to formula (2);

$$
\begin{array}{ll}
\mathrm{Y}_{\mathrm{m}} & =53 \% \\
\mathrm{Z} & =66 \% \\
\mathrm{~V} & =79 \%
\end{array}
$$

Then substituting:

$$
53 \% \times \frac{1}{1-(66 \% \times 79 \%)}=(0.53 \times 2.08)=1.1024
$$

Step 9.

This step called for the derivation of total increase in metropolitan income due to tourist spending in 1980, which was obtained by multiplying the total tourist expenditure by the tourist income multiplier. That is: $\$ 331,500,900.90 \times 1.1024=\$ 365,446,593.20$, where direct tourist-generated income in the metropolitan area was $\$ 177,982,833.71$ (from Table II) and the indirect touristgenerated income was $\$ 365,446,593.20$. Total impact (direct and indirect) was $\$ 177,982,833.71+\$ 365,446,593.20=$ $\$ 543,429,426.91$. 
Employment Multiplier

As indicated in Chapter IV, there is no difference between the income and employment multiplier models applied in the research, except that the dollar income was converted to employment. Therefore, the tourist-generated employment with the subsequent multiplier effect was determined by using the 1977 Census of Retail Trade figures for Portland S.M.S.A. and tourist expenditure figures for Portland in 1980. The following step analysis was used:

1. The question here was how many dollars did it take to create one tourist-related job by type of business category? To obtain the number of jobs directly created in 1980 for all tourist-related business sectors, the 1977 sales per employee by sector was adjusted for inflation. The change in the Consumer Price Index between 1977 and 1980 was $36 \%$ percent (U.S. Department of Commerce and Labor, Bureau of Census and Statistics, 1980 and 1977), which provided an adjustment factor 10 of 1.36 . Using the adjustment factor, the 1977 sales per employee in each business category was multiplied by 1.36, which resulted in an estimated 1980 sales figure per employee. Thus, the number of dollars taken to create one job in each sector was determined (see Table III).

10 The 1980 figures were derived with an inflation index of 1.36. That is between 1977-1980, a brand of good that was sold for $\$ 1$ in 1977 would cost $\$ 1.36$ in 1980. (36\% price increase). 
TABLE III

SALES PER EMPLOYEE BY BUSINESS

CATEGORY PORTLAND S.M.S.A.

1977-1980

\begin{tabular}{lrrrr}
\multicolumn{1}{c}{ Business Category } & Sales $(\$)$ & $\begin{array}{c}\text { Number } \\
\text { Employee }\end{array}$ & $\begin{array}{c}1977 \\
\text { Annual } \\
\text { Employee }(\$)\end{array}$ & $\begin{array}{c}1980 \\
\text { Employee }\end{array}(\$)$ \\
\hline Lodging Establishments & $9,545,000$ & 5,305 & $\$ 17,993.21$ & $\$ 24,470.76$ \\
Gasoline Service Stations & $299,784,000$ & 3,807 & $\$ 78,745.47$ & $\$ 107,093.84$ \\
Eating and Drinking & $459,316,000$ & 27,301 & $\$ 16,824.15$ & $\$ 22,880.84$ \\
Establishments & $15,457,000$ & 714 & $\$ 21,228.29$ & $\$ 28,870.47$ \\
Movie Theatres & $356,818,000$ & 5,420 & $\$ 65,833.58$ & $\$ 89,533.67$ \\
Miscellaneous Retailing & & & &
\end{tabular}

Source: U.S. Dept. of Commerce, Bureau of the Census: Census of Retail Trade, "Major Retail Centers in Standard Metropolitan Statistical Areas" and Geographic Area Series, Feb. 1980, Table 38-29 and 38-16.

(2) U.S. Dept. of Labor, Bureau of Labor Statistics: "News U.S. Dept. of Labor,Consumer Price Index - Urban (C.P.I. - U) 1977-1980". 
2. The tourist-generated employment in each touristrelated business sector or category was derived by dividing the 1980 tourist expenditure in each business category by the estimated 1980 sales per employee (see Table IV). 3. The tourist-generated employment that remained in the metropolitan area was determined as follows: As indicated earlier, if the local restaurants, for example, were able to purchase food from farmers in the metropolitan area, much of the tourist spending in that category would result in more local employment than when the food had to be imported. The percentages of goods and services from the metropolitan area that were utilized by each business category as obtained from interviews of the tourist-related business proprietors were used to multiply the number of employees in each business category. The result was an estimated touristgenerated employment that remained in the metropolitan area as shown in Table $\mathrm{V}$. 
TABLE IV

VOLUME AND PATTERN OF TOURIST SPENDING WITH

EMPLOYMENT BY SECTOR

\begin{tabular}{lcccc}
\multicolumn{1}{c}{ Business Category } & $\begin{array}{c}\text { \% of } \\
\text { Total } \\
\text { Spent }\end{array}$ & Dollars Spent & $\begin{array}{c}\text { Sales/ } \\
\text { Employee }(\$)\end{array}$ & $\begin{array}{r}\text { Number } \text { Employment } \\
\text { Employm }\end{array}$ \\
\hline Lodging Establishments & 23 & $\$ 76,245,207.21$ & $\$ 24,470.76$ & 3,116 \\
Gasoline Service Stations & 20 & $\$ 66,300,180.18$ & $\$ 107,093.84$ & 619 \\
$\begin{array}{l}\text { Eating and Drinking } \\
\text { Establishments }\end{array}$ & 32 & $\$ 106,080,288.30$ & $\$ 22,880.84$ & 4,636 \\
Movie Theatres & 8 & $\$ 26,520,072.07$ & $\$ 28,870.47$ & 919 \\
Miscellaneous Retailing & 17 & $\$ 56,355,153.15$ & $\$ 89,533.67$ & 629 \\
\hline Total & 100 & &. & 9,919
\end{tabular}

Source: Derived from Tables I and III. 
TABLE V

TOURIST-GENERATED EMPLOYMENT THAT

REMAINED IN THE METROPOLITAN AREA

Business Category Percent Employment

\begin{tabular}{lcc}
\hline Lodging Establishments & 81 & 2,524 \\
Gasoline Service Stations & 32 & 198 \\
Eating and Drinking & 72 & 3,338 \\
Establishments & 15 & 138 \\
Movie Theatres & 26 & 164 \\
Miscellaneous Retailing & & \\
\hline
\end{tabular}

Total

6,362

Source: Survey of tourist-related business proprietors and Table IV.

4. The percent of tourist expenditure that directly

increased metropolitan employment was derived. This figure

was a weighted average of all tourist-related business

categories. The weights were the tourist-generated

employment pattern and the percent of tourist-generated

employment that remained in the metropolitan area (see

formula $2 \mathrm{~b})$. The next several steps were the computations of

the percent of local income spent in the metropolitan area, percent of goods and services sold locally and produced locally, and the multiplier. These calculation procedures were fully explained in the methodological steps presented in computing the income multiplier; it seems unnecessary to repeat them here. 
From those previous calculations, the following values were obtained:

(a) Percent of tourist expenditures that directly increased metropolitan employment $=53 \%$

(b) Percent of local income that was spent in the metropolitan area $=66 \%$

(c) Percent of goods and services sold locally that were produced within the metropolitan area $=79 \%$

(d) The tourism multiplier $=1.1024$

That is, for every job created in the metropolitan area due to tourist spending, metropolitan employment increased by approximately one job.

5. To determine the total increase in metropolitan employment due to tourist spending in 1980, the total tourist-generated employment in all sectors was multiplied by an index figure of 1.1024 . Thus, $9,919 \times 1.1024=10,935$ jobs. To determine the total jobs (direct and indirect), created due to tourist spending, the direct $(6,362)$ and indirect $(10,935)$ jobs derived in the above computations were summed: $\quad 6,362+10,935=17,297^{\circ}$ jobs. It was also necessary to compute the monetary benefits and costs associated with tourism in the metropolitan area.

\section{Tourist-Generated Business Property Tax Revenues}

In determining the tourist-generated property tax revenues, 315 tourist-related businesses in the metropolitan area were sampled. From these samples, it was estimated 
that $\$ 13,626,556,63$ was paid in property taxes by these businesses. The tourist-generated share of these revenues was $\$ 5,985,993.87$, as shown in the following tables. 
TABLE VI

TOURIST-RELATED BUSINESSES: SAMPLE ASSESSED VALUES AND PROPERTY TAXES

\begin{tabular}{|c|c|c|c|c|c|c|}
\hline Type of Business & $\underset{\text { Size }}{\text { Sample }}$ & $\begin{array}{l}\text { Percent } \\
\text { Covered }\end{array}$ & $\begin{array}{l}\text { Assessed } \\
\text { Value }\end{array}$ & $\begin{array}{l}\text { Average } \\
\text { Values }\end{array}$ & $\begin{array}{c}\text { Property } \\
\text { Taxes }\end{array}$ & $\begin{array}{r}\text { Average } \\
\text { Taxes }\end{array}$ \\
\hline Lodging Establishaents & 58 & 31 & $\$ 84,061,439.86$ & $\$ 1,449,335.17$ & $\$ 1,621,530.36$ & $\$ 27,957.42$ \\
\hline Eating and Drinking Establishmenta & 105 & 6 & $\$ 13,889,873.55$ & $\$ 132,284 \cdot j 1$ & $\$ 288,775.20$ & $\$ 2,750.24$ \\
\hline Movie Theatres & 36 & 59 & $\$ 12,522,200.04$ & $\$ 347,838.89$ & $\$ 342,949.32$ & $\$ 9,526.37$ \\
\hline Total & 315 & & $\$ 127,828,291.10$ & $\$ 2,246,641_{6} .85$ & $\$ 2,581,532.28$ & $\$ 46.325 .53$ \\
\hline
\end{tabular}


TABLE VII

TOURIST-RELATED BUSINESSES: ESTIMATED VALUES AND PROPERTY TAXES

\begin{tabular}{|c|c|c|c|c|c|}
\hline Type of Business & $\begin{array}{l}\text { Number of } \\
\text { Businesses }\end{array}$ & $\begin{array}{l}\text { Mean } \\
\text { Values }\end{array}$ & $\begin{array}{l}\text { Estimated } \\
\text { Value }\end{array}$ & $\begin{array}{l}\text { Mean } \\
\text { Taxes }\end{array}$ & $\begin{array}{c}\text { Estimated } \\
\text { Taxes }\end{array}$ \\
\hline Lodging Establishment & 198 & $\$ 1,449,335.17$ & $\$ 275,373,682.30$ & $\$ 27,957.42$ & $\$ 5,311,909.80$ \\
\hline Eating and Drinking Establishments & 1,849 & $\$ 132,284.51$ & $\$ 244,594,59.00$ & $\$ 2,750.24$ & $\$ 5,085,193.76$ \\
\hline Movie Theatres & 61 & $\$ 347,838.89$ & $\$ 21,218,172.29$ & $\$ 9,526.37$ & $\$ 581,108.57$ \\
\hline Total & 2,939 & $2,246,644.85$ & $\$ 677,861,312.44$ & & $\$ 13,626,556.63$ \\
\hline
\end{tabular}

Note: Estimated property values = mumbers of businesses multiplied by mean property values

(column $2 x$ column 3 ).

by 
TABLE VIII

TOURIST-GENERATED BUSINESS PROPERTY TAX REVENUES

\begin{tabular}{|c|c|c|c|}
\hline Type of Business & $\begin{array}{l}\text { Total Tax } \\
\text { Revenues }\end{array}$ & $\begin{array}{l}\text { Tourist As A } \\
\text { Percent of Total }\end{array}$ & $\begin{array}{l}\text { Tourist Share } \\
\text { of Revenues }\end{array}$ \\
\hline Lodging Establishments & $\$ 5,311,909.80$ & $85 \%$ & $\$ 4,515,123.33$ \\
\hline Gasoline Service Stations & $\$ 2,088,375.30$ & $18 \%$ & $\$ 375,907.55$ \\
\hline $\begin{array}{l}\text { Eating and Drinking } \\
\text { Establishments }\end{array}$ & $\$ 5,085,193.76$ & $30 \%$ & $\$ 1,525,558.13$ \\
\hline Movie Theatres & $\$ 581,108.57$ & $17 \%$ & $\$ 98,788.46$ \\
\hline Miscellaneous Retailing & $\$ 559,969.20$ & $21 \%$ & $\$ 117,593.53$ \\
\hline Total & $\$ 13,626,556.63$ & & $\$ 6,632,971$ \\
\hline \multicolumn{4}{|c|}{$\begin{array}{l}\text { Note: The percent of the business gross sales to tourists as obtained from the } \\
\text { survey of tourist-related businesses was applied in the derivation of the } \\
\text { tourist generated property tax revenues. The procedure applied in the } \\
\text { overall computation is as shown in formula (1b). }\end{array}$} \\
\hline
\end{tabular}


Tourist-Generated Business License Revenues

As indicated earlier, two types of business license revenues are collected in the metropolitan area. One is the State-required business license fees on lodging and eatingdrinking establishments. These fees are administered by County Health Departments. The other is the city business license fees imposed on businesses located within city jurisdictions. The revenues collected from these sources are as shown in Table IX and $X$, and the percent of gross sales to tourists is again applied to derive the portion of these revenues attributable to tourism. 
TABLE IX

STATE-REQUIRED TOURIS'T-RELATED BUSINESS LICENSE REVENUE: TRI-COUNTY AREA

\begin{tabular}{|c|c|c|c|c|c|c|}
\hline Type of Business & Clackamas & Multnomah & Washington & Total & $\begin{array}{l}\text { Tourism As } \\
\text { A Percent } \\
\text { of Total }\end{array}$ & $\begin{array}{l}\text { Tourist } \\
\text { Share of } \\
\text { Revenue }\end{array}$ \\
\hline Lodging Establishments & $\$ 19,725$ & $\$ 47,567$ & $\$ 27,000$ & $\$ 94,292$ & $85 \%$ & $\$ 80,148.20$ \\
\hline Eating and Drinking Establisments & $\$ 77,125$ & $\$ 263,140$ & $\$ 5,000$ & $\$ 390,265$ & $30 \%$ & $\$ 117,079.50$ \\
\hline Total & $\$ 96,850$ & $\$ 310,707$ & $\$ 77,000$ & $\$ 484,557$ & & $\$ 197,227.70$ \\
\hline
\end{tabular}

Source: Clackamas County, Washington County Environmental Health Departments, and Multnonah County Health Sanitation Department; "Annual Financial Report" 1980-81. 
TABLE $X$

ALL CITIES TOURIST-RELATED BUSINESS LICENSE REVENUES

Tourist As Tourist A Percent Share of

\begin{tabular}{lrrr}
\multicolumn{1}{c}{ Type of Business } & Total & $\begin{array}{c}\text { A Percent } \\
\text { of Total }\end{array}$ & $\begin{array}{c}\text { Share of } \\
\text { Revenue }\end{array}$ \\
\hline Lodging Establishments & $\$ 26,810.40$ & $85 \%$ & $\$ 22,788.84$ \\
Gasoline Service Stations & $\$ 79,172,00$ & $18 \%$ & $\$ 14,250.96$ \\
$\begin{array}{l}\text { Eating and Drinking } \\
\text { Establishments }\end{array}$ & $\$ 205,496.65$ & $30 \%$ & $\$ 61,649.00$ \\
$\begin{array}{l}\text { Movie Theatres } \\
\text { Miscellaneous Retailing }\end{array}$ & $\$ 18,618.60$ & $21 \%$ & $\$ 3,909.91$ \\
\hline
\end{tabular}

Total

$\$ 332,387.45$

$\$ 102,987.07$

Source: All Cities Business License Divisions, "Annual Reports" 1980-81.

Adding the tourist share of the two revenue sources, the total tourist-generated business license revenues for the metropolitan area was derived: $\$ 197,227.70+\$ 102,987.07=$ $\$ 300,214 \cdot 77$.

Tourist-Generated Fuel Tax and Room Occupation Tax Revenues

The total fuel tax revenues sent to the metropolitan area by the State Highway Division was $\$ 21,055,554 \cdot 48$. Again, the percent of gross sales to tourists was used to determine the amount attributable to tourism:

Percent of gross sales to tourists $=18$ percent.

$\$ 21,055,554.48 \times 0.18=\$ 2,622,806.46$.

Revenues from room occupation taxes were $\$ 3,689,895.50$. Percent of business gross sales to tourists was used to derive the amount due to tourist spendings; 
percent of gross sales to tourists at lodging establishments was derived earlier ( 85 percent). Then, \$3,689,895.50 X $0.85=\$ 3,136,411.18$.

Tourist-Generated Revenues From Public Amusement and

Recreation Facilities, and Parking Revenues

As discussed previously, the percent of tourist attendance at the public amusement and recreation facilities was used to determine the amount of revenues attributable to tourism as shown in Table XI. 
TABLE XI

TOURIST-GENERATED REVENUES FROM PUBLIC AMUSEMENT AND RECREATION FACILITIES

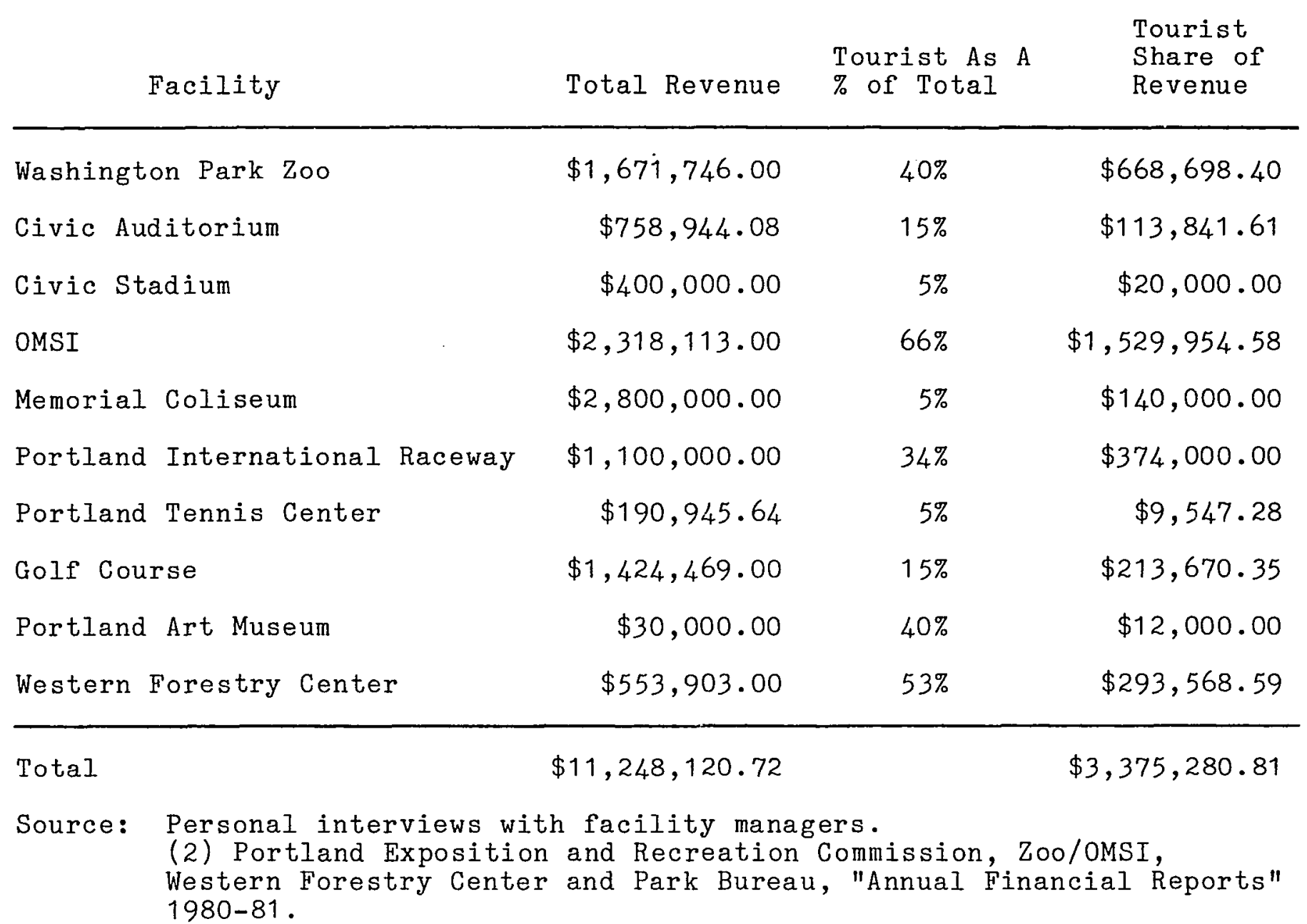


For tourist-generated parking revenues, the ratio of tourist person-days to total annual person-days in the metropolitan area was used to multiply the total parking revenues, as shown by formula (1d).

Substituting; $\frac{14,826,135}{398,210,090} \times \frac{\$ 4,378,561.84}{1}=\$ 163,022.37$

Property Taxes Paid by People Employed Due to Tourist Spending

To determine the property taxes paid by people employed due to tourist spending in the metropolitan area, the following computation procedures were performed. (Earlier in the employment multiplier model, 6,362 direct and 10,935 indirect tourist-generated jobs were found to exist in the metropolitan area.)

(1) To convert these direct jobs into monetary terms, reference was made to the Oregon Covered Employment and Payrolls by Industry and County, 1979, as shown in Table XII. 


\section{TABLE XII}

STATE OF OREGON ANNUAL EARNINGS PER EMPLOYEE BY TYPE OF BUSINESS

\begin{tabular}{|c|c|c|c|c|c|}
\hline Business Category & $\begin{array}{l}\text { Average } \\
\text { Employment }\end{array}$ & $\begin{array}{l}\text { Total } \\
\text { Annual } \\
\text { Payroll }\end{array}$ & $\begin{array}{l}\text { Annual } \\
\text { Payroll Per } \\
\text { Employee } \\
1979\end{array}$ & $\begin{array}{l}\text { Percent } \\
\text { Increase } \\
1979-80\end{array}$ & $\begin{array}{l}\text { Annual } \\
\text { Payroll Per } \\
\text { Employee } \\
\quad 1980\end{array}$ \\
\hline Lodging Establishments & 14,365 & $\$ 78,272,430$ & $\$ 5,448.83$ & $7.4 \%$ & $\$ 5,852.04$ \\
\hline Gasoline Service Stations & 7,891 & $\$ 55,236,717$ & $\$ 7,000.00$ & $7.4 \%$ & $\$ 7,518.00$ \\
\hline $\begin{array}{l}\text { Eating \& Drinking } \\
\text { Establishments }\end{array}$ & 67,280 & $\$ 319,004,088$ & $\$ 4,741.44$ & $7.4 \%$ & $\$ 5,092.31$ \\
\hline Movie Theatres & 1,589 & $\$ 5,576,893$ & $\$ 4,149.46$ & $7.4 \%$ & $\$ 4,456.52$ \\
\hline Miscellaneous Retailing & 2,499 & $\$ 17,749,076$ & $\$ 1,702.47$ & $7.4 \%$ & $\$ 7,628.05$ \\
\hline
\end{tabular}

Source: (1) Research and Statistics Section, State of Oregon Employment Division, Department of Human Resources. 
(2) The annual employee earnings by business category were determined by multiplying the annual payroll per employee by the number of direct tourist-generated employment that remained in the metropolitan area (see Formula 1e). Illustrating with lodging estblishments $Y_{i}=$ $\$ 5,852.04 \cdot E_{i}=2,524$ jobs, then $\$ 5,852.04 \times 2,524=$ $\$ 14,770,548.96$. The same computation procedure was performed for the other business categories, resulting in total direct tourism-generated earnings of $\$ 35,123,243,70$, as shown below.

\section{TABLE XIII}

DIRECT TOURISM-GENERATED EMPLOYMENT

EARNINGS IN THE METROPOLITAN AREA, 1980

Annual Number Payroll Per All Employee Business Category of Jobs Employee Annual Earnings

$\begin{array}{lrrr}\text { Lodging Establishments } & 2,524 & \$ 5,852.04 & \$ 14,770,548.96 \\ \text { Gasoline Service Stations } & 198 & \$ 7,518.00 & \$ 1,488,564.00\end{array}$

Eating and Drinking

Establishments $\quad 3,338 \quad \$ 5,092.31 \quad \$ 16,998.130 .78$

Movie Theatres $\quad 138 \quad \$ 4,456.52 \quad \$ 614,999.76$

Miscellaneous Retailing $\quad 164 \quad \$ 7,628.05 \quad \$ 1,251,000.20$

$\begin{array}{ll}\text { Total } & 6,362 \\ & \$ 35,123,243.70\end{array}$

Source: Derived from Tabes V and VII.

(3) As indicated earlier, the indirect tourismgenerated employment as derived in the employment multiplier could have accrued in the various sectors that supplied goods and services to the tourism-related businesses 
covered in the study. These jobs might have been skilled or unskilled. But without specific knowledge of the manpower levels involved and the appropriate pay scales, the study relied on the Federal minimum wage level ( $\$ 3.35$ per hour), to gauge the payroll earnings from these jobs. The estimate was based on a forty hour work week for twelve months (160 hours per month X $12=1,920$ hours per year). To derive the annual earnings per employee, the $\$ 3.35$ wage level was multiplied by 1,920 hours: $\$ 3.35 \times 1,920=\$ 6,432$ per year. Using the annual earnings per employee to multiply the total indirect tourism-generated jobs, the total indirect employment earnings were derived: $\$ 6,432 \times 10,935=$ $\$ 70,333,920$. The sum of the direct and indirect tourism-generated employment earnings formed the total tourism-generated payroll in the metropolitan area: $\$ 35,123,243.70+\$ 70,333,920.00=\$ 105,457,163.70$.

(4) Having derived the tourism-generated payroll earnings in the metropolitan area, a determination of the property tax revenues from these earnings was made, as follows: The relationship between earned income and property taxes was first determined by computing an average metropolitan property tax ratio. The total metropolitan property tax revenue was divided by the metropolitan adjusted gross income. 
TABLE XIV

TOTAL METROPOLITAN PROPERTY TAX REVENUES BY COUNTY

County Revenues

\begin{tabular}{ll}
\hline Clackamas & $\$ 118,313,807.54$ \\
Multnomah & $\$ 289,878,286.65$ \\
Washington & $\$ 124,586,150.50$ \\
\hline Total & (1) $\begin{array}{l}\text { Clackamas County } \\
\text { Source: }\end{array}$ \\
& (2) $\begin{array}{l}\text { Multnomah County } \\
\text { Division of assessment \& } \\
\text { Taxation (1981) } \\
\text { Washington County } \\
\text { Department of Assessment \& } \\
\text { Taxation (1981) }\end{array}$
\end{tabular}

Then the metropolitan gross income for 1979 which was $\$ 3,138,715,000$ (U.S. Department of Commerce, Bureau of Economic Analysis, 1981), was adjusted by an inflation index of 13.3 percent $(\$ 5,138,715,000 \times 13.3 \%=$ $\$ 3,556,164,000.095)$. The result was a metropolitan adjusted gross income of $\$ 3,556,164,000.095$.

Then, $\frac{\$ 532,778,244.69}{\$ 3,556,164,000.095}=0.15$

The tourism-generated payroll in the metropolitan area was then multiplied by the above ratio, according to formula $(1 \mathrm{f})$.

Substituting,

$$
\frac{\$ 105,457,163.70}{1} \times \frac{\$ 532,778,244.69}{\$ 3,556,164,000.095}=\$ 15,818,574.56
$$


To determine the average revenues per tourist personday in the metropolitan area, all the benefits as computed above were summed and divided by the total tourist persondays (see formula 1). The total tourism-induced revenues in the metropolitan area are as shown in Table XV. TABLE XV METROPOLITAN TOURISM-INDUCED REVENUES Revenue Source Amount (\$)

Business Property Tax Revenues

Business License Revenues

Gasoline Tax Revenues

Indirect Property Tax Revenue

Parking Revenues

Public Amusement \& Recreation Revenue

Room Occuption Tax Revenues

$$
\begin{array}{r}
\$ 6,632,971.00 \\
\$ 300,214.77 \\
\$ 2,622,806.48 \\
\$ 15,818,574.56 \\
\$ 1,630,222.37 \\
\$ 3,375,280.81 \\
\$ 3,136,411.18
\end{array}
$$

Total

$\$ 33,516,481.17$

Determining average revenues per tourist person-day;

where, total tourist person-days $=14,826,135$.

Total tourist-induced revenues $=\$ 33,516,481.17$.

Then average revenues per tourist person-day = $\frac{\$ 33,516,481.17}{14,826,135}=\$ 2.26$

Hence, the average tourist-induced revenues per tourist person-day was $\$ 2.26$ during the study period. 
Computing Monetary Costs

Beside the monetary benefits discussed above, the metropolitan area incurred some monetary costs from services provided to tourists while in the area. As indicated earlier, the method applied here was computation of average costs per person-day. The metropolitan governments' expenditures hence were summed and then divided by the total annual person days as shown in formula (4). A summary of the cost breakdown is shown in Table XVI, while the more detailed version is shown in Appendix F.

TABLE XVI

SUMMARY: METROPOLITAN PORTLAND EXPENDITURES 1980-81 Name of Political Unit Expenditures (\$)

\begin{tabular}{lc} 
Clackamas County & $\$ 48,866,022$ \\
Multnomah County & $\$ 151,266,138$ \\
Washington County & $\$ 33,265,674$ \\
All Cities & $\$ 405,939,515.34$ \\
AlI Rural Fire Area Protection & \\
Districts & $\$ 40,281,902$ \\
All Special Purpose Districts & $\$ 6,480,791$ \\
All Service Districts (except M.S.D.) & $\$ 18,107,280$ \\
All Water Districts & $\$ 23,705,280$ \\
Metropolitan Service District & $\$ 14,039,725$ \\
\hline & \\
Total & $\$ 746,752,327.34$ \\
Source: Audit Division, Secretary of State's 0ffice, & Information File - \\
\hline & Computer Print Out" 1980-81.
\end{tabular}


It was shown earlier that the total annual person days in the metropolitan area were $398,187,590$. Solving for cost per person-day; $\quad \frac{\$ 746,752,327.34}{398,187,590}=\$ 1.88$

To derive the costs of providing services to tourists during the study period, the total tourist person-days were multiplied by the cost per person-day as shown in the

formula: $C_{\text {pd }} X T_{p d}=M_{c t}$.

where $\mathrm{C}_{\mathrm{pd}}=\$ 1.88$

$\mathrm{T}_{\mathrm{pd}}=14,826,135$ tourist person-days.

Substituting;

$$
\$ 1.88 \times 14,826,135=\$ 27,873,133.80
$$

Comparing Monetary Costs with Benefits

For a complete analysis of the tourism impact, the monetary costs were weighed against the monetary benefits. This was achieved by subtracting the total metropolitan service costs from the total tourism-generated revenues. The total tourism-induced revenues as indicated in Table XV were $\$ 33,516,481.17$, and the total metropolitan cost of providing services to tourists was $\$ 27,873,133.80$. Subtracting costs from revenues: $\$ 33,516,481.17$ $\$ 27,873,133.80=\$ 5,643,347.37$, resulting in the net monetary benefits in terms of revenues derived by the metropolitan area from tourist spending. 
CHAPTER VI

\section{FINDINGS AND VALIDATION OF METHOD}

The initial question asked in this study was: "Do monetary costs attributable to tourism outweigh the monetary benefits derived from tourism in the metropolitan area, or is the metropolitan taxpayer really subsidizing the tourism industry?" The analytical answer to this question and findings relating to the research hypotheses are presented in this chapter.

Hypothesis No. 1

It was hypothesized that tourism provides significant employment creation and income generation possibilities in the Portland metropolitan area. Results of the analysis supported this hypothesis. The research found that there were income and employment multipliers of 1.1024, which means that for every dollar received from tourist expenditures, the resultant increase in metropolitan income was approximately $\$ 1.10$. Also, for every job created due to tourist spending in the area, the increase in metropolitan employment was one job. It is important here to note that these new jobs and income were created through recycling of the initial tourist dollar in the area.

The study also found that of the $\$ 331,500,900.90$ spent by tourists during the study year, only 53 percent $(\$ 177,982,833.71)$ remained in the metropolitan area as 
income - 47 percent leaked out of the area economy for payment of imported goods and services used by the tourists while in the area. Also, of the 9,919 jobs resulting from tourist expenditures, only 64 percent $(6,362$ jobs) remained in the metropolitan area. Thus, analysis of the total tourist expenditures in the area in 1980, less leakages, provided the following direct and indirect income and employment picture:

TABLE XVII (A)

TOTAL TOURISM-GENERATED INCOME

\begin{tabular}{lc}
\multicolumn{1}{c}{ Source } & Amount \\
Direct Income & $\$ 177,982,833.71$ \\
Indirect Income & $\$ 365,466,593.20$ \\
\hline Total & $\$ 543,429,426.91$
\end{tabular}

TABLE XVII (B)

TOTAL TOURISM-GENERATED EMPLOYMENT Source Number of Jobs

Direct Employment $\quad 6,362$

Indirect Employment 10,935

Total

17,297

Hypothesis No. 2

The results of the analyses also strongly supported the second major hypothesis: tourism creates more benefits than it causes service costs to the metropolitan area. Metropolitan service costs per tourist person-day were found to be $\$ 1.88$, and revenue per tourist person-day was $\$ 2.26$. 
When the costs per tourist person-day were multiplied by the total tourist person-days $(14,826,135)$, the result was $\$ 27,873,133.80$ during the study period. Also, all touristgenerated revenues were found to total $\$ 33,516,481.17$ (see Table XV). Subtracting the monetary costs from the monetary benefits, a net monetary benefit of $\$ 5,643,347.37$ was realized. From this finding, it is evident that the metropolitan area enjoyed a net benefit of 38 cents per tourist person-day, during the study year.

\section{Minor Hypothesis}

The results of the analysis lent some support to the hypothesis that, although tourism-related jobs are lowpaying, they are significant in terms of minority employment and indirect property tax revenue due to tourism-generated payroll in the area. Results from a survey of 315 touristrelated businesses in the metropolitan area indicated that 59 percent of their employees were minority as defined in Chapter III.

Minority employment of 59 percent is relatively significant. As can be seen from Table XVIII, when the analysis is directed to a combination of all tourist-related businesses in the metropolitan area, the results fairly support the hypothesis. But when it is directed to the individual tourist-related business categories, e.g., gasoline service stations, the results weaken the hypothesis. It is important to note at this point that some 
TABLE XVIII

DISTRIBUTION OF TOURIST-GENERATED EMPLOYMENT

\begin{tabular}{lcccc}
\multicolumn{1}{c}{ Business Category } & Minority & $\begin{array}{c}\text { Non } \\
\text { Minority }\end{array}$ & $\begin{array}{c}\text { Total } \\
\text { Employment Minority }\end{array}$ & $\begin{array}{c}\text { Percent } \\
\text { Mon }\end{array}$ \\
\hline Lodging Establishments
\end{tabular}


tourist-related businesses in the area employ a high percentage of minorities, while some do not.

It was also found that tourism-generated payroll in the metropolitan area amounted to $\$ 105,457,163.70$, and the indirect property tax revenue from this payroll was $\$ 15,818,574.56$, figures of some significance. Moreover, this segment of the population is the most impacted by unemployment. If these minorities had not been employed in tourism, there is no evidence that they would have been employed in other industries. If unemployed, they would have been entitled to consume many governmentally-subsidized services such as housing, food stamps, medical care etc. As a result of tourism employment, they receive fewer of these services, which in turn reduces the strain on the metropolitan government budgets. Therefore, no opportunity costs are paid by the metropolitan area in relation to tourism.

\section{Other Findings}

Additional analytical findings relate to the amount of money bartenders, waitresses, and bus persons accumulate in tips during a typical working day. As indicated in the previous chapter, sixty hotel and eating-drinking establishments' managers were interviewed to ascertain whether the tip rate has changed or remained the same between 1975 and 1980. Results of the analysis indicated that 77 percent of the interviewees said that the tip rate 
had remained unchanged, while 15 percent indicated that it had increased; 8 percent noted that it had declined. A number of reasons were given for the responses made. The most important one was that it is in the American tradition to provide tips while receiving services at the eating and drinking establishments. Hence, people look at the total bill and tip 10-15 percent of it. Based on these results, there is strong evidence to believe that the tip rate has remained unchanged over the years. That is, as prices have gone up due to inflation, tips have also increased in amount, but not in rate.

A study on wages and tips of waitresses, bartenders and bus persons (Kelleher, 1976), indicated that tips as percent of earnings for employees of cocktail lounges in Portland was 39 percent; and at full-course restaurants, it was 31 percent. Assuming a $\$ 3.35$ per hour wage level, employees at cocktail lounges made $\$ 536$ a month plus $\$ 209.04$ in tips, for a total of $\$ 745.04$ per month $(\$ 8,940.48$ per yera). Also, an employee at a full course restaurant earned $\$ 702.16$ per month or $\$ 8,425.92$ per year. In both cases, yearly income indicates that the employee is likely not receiving welfare.

\section{VALIDATION OF METHOD}

Technical criteria (reliability, continuity and comprehensiveness) are always of paramount importance in the research analytical procedure if meaningful conclusions are 
to be drawn. Measurements should be made in a way that can be repeated in successive periods and reliably show the changes that have occurred in the amount of tourism in the area. Also, the measurements should cover all relevant and significant kinds of tourism activity. Most of the methods to measure economic impact of tourism incorporate one or more models, depicting mathematical relationships among and within groups of tourism industry components to predict the total impact of the industry from actual measurement of a smaller number of these components (Goeke, 19.81). In general, the procedures include one or a combination of the following types.

1. Analysis of secondary data, e.g., tax records, traffic counts, etc.

2. Surveys of households of possible or potential tourists to the area.

3. Surveys of tourists to and/or within the impact area.

4. Surveys of tourism-related businesses in the impact area.

These general methods have been adapted to unique and ongoing tourism impact studies by a variety of individuals, institutions, and organizations.

Validating the Research Data and Method

The analysis as carried out in this investigation incorporated all the above methods except surveys of 
households of possible or potential tourists to the area. The data on the patterns and volume of tourist spending in the metropolitan area were collected from the 1980 Oregon State Department of Transportation Tourist Survey study - a pool of data already tested and approved. Other major secondary data utilized in the study were metropolitan service expenditures, assessed property values, and taxes. These are data collected and reported annually by the appropriate metropolitan government departments, which are, by definition, nonbiased.

A primary data source used in the study was a random sample survey of 315 tourist-related business proprietors in the metropolitan area, conducted by the author (see Chapter III). While utilizing a table of random numbers, the study assured that every tourist-related business in the area had an equal chance of appearing in the sample. A sample this large ( 315 businesses) is representative. During the interview, the proprietors were asked to estimate the percent of their gross receipts that came from tourists. Thus, the study assumed that the proprietors were astute observers of their business patterns, capable of making reliable estimates of the percentage of their businesses originating from tourists and local residents. It is based on the proprietors' self-analysis of their markets, as determined by careful bookkeeping procedures. The majority of these proprietors update their analyses at regular intervals. In social science research, it is normal to 
assume that transactions and interactions between human beings have some credibility. For example, the events surrounding and resulting from business transactions can be based on some trust in the reliability of what went on during the encounter, especially when such data came fromthe most responsible business representative. Such has proven to be the case in this research. Therefore, it is important to note that, as with all self-report data, it is assumed that the level of respondent's reporting is as accurate for these data as any other previous research involving selfreport.

Arithmetic means from the survey results were used to estimate the amount of property taxes and other revenues attributable to tourism in the metropolitan area because they represented best and most common measures of central tendencies (Taylor, 1977).

Analytical findings with the income and employment multipliers as applied in this research indicated multiplier effects of 1.1024 . This result was compared to multipliers produced for other regions by other methods as shown below. A tourist impact study for Walworth County, S.E. Wisconsin in 1963 (Katler and Lord, 1968), produced a tourist regional impact multiplier of 1.80. A Sullivan, Pennsylvania study, produced a tourist impact multiplier of 1.62 (Gamble, 1963). Also, a tourism impact study for the Pacific and Far East came up with a multiplier of 3.27 (Clement, 1961), while New Hampshire and Hawaii studies produced multipliers of 
1.6 - 1.7 (New Hampshire State Planning Project, 1965), and

$0.9-1.3$ (Craig, 1963). In this context, the Portland metropolitan area tourism multiplier index ${ }^{11}$ of 1.1024 reported in this study, seems reasonable.

The methodology used in the derivation of the average monetary benefits and costs is straightforward. To compute the metropolitan service costs per person-day, the only data needed were the operating metropolitan governments' expenditures for the period covered, and the resident and tourist person-days combined. When the expenditures were divided by the total person-days, the result was the average cost of maintaining one person per day in the area. Similarly, to compute average revenues per tourist person-day in the area, all tourist-generated taxes and other revenues were summed and divided into the total tourist person-days in the metropolitan area. The result was the amount of revenues realized by the area per tourist personday. When the average costs per person-day were subtracted from the average revenues per tourist person-day, the result was the net monetary benefit derived by the metropolitan area per tourist person-day. Thus, because of the relative availability of the data utilized in this research, the straightforwardness and comprehensive nature of the above

${ }^{11}$ The multiplier model applied in the derivation of the above index, does not have the unit 1 attached to the overall model. If the unit 1 had been attached to the formula, the index would have been 2.1024 . 
methodology, there is no doubt that it is replicable. 
CHAPTER VII

SUMMARY, DISCUSSION AND CONCLUSION

\section{SUMMARY}

This study explored the monetary benefits and costs attributable to tourism in the Portland metropolitan area in 1980. Two research questions were raised: (1) Do monetary costs attributable to tourism outweigh the monetary benefits derived from tourism in the metropolitan area? (2) Is the metropolitan taxpayer really subsidizing the tourism industry? Relating to these questions, two major hypotheses were stated:

(1) Tourism in the metropolitan area provides significant employment creation and income generation possibilities.

(2) Tourism creates more benefits than it causes service costs to the metropolitan area.

Pursuant to the above research questions and hypotheses, income and employment multipliers, and average benefits and costs per tourist person-day were computed. Although the monetary benefits and costs were the crux of the study, the income and employment multipliers were first computed to derive some useful indices to weigh costs against benefits due to tourism in the area.

The analysis yielded some interesting results. It was found that income and employment multipliers from tourist 
spendings in the area were 1.1024 during the study period. That is, for every dollar spent by tourists in the area, there was approximately one additional dollar created through secondary expenditures or recycling of the initial tourist dollar. Also, for every job created due to the tourist expenditure, another job was generated in the area over time. Tourism generated more than $\$ 543$ million in the metropolitan area during the study period. Also, jobs directly and indirectly supported by tourist dollars in the area totaled 17,297 (full-time equivalent).

Monetary benefits in terms of taxes and other revenues from tourism were found to be highly significant. Metropolitan costs (services provided to tourists while in the area) were $\$ 27,873,133.80$, whereas monetary benefits were $\$ 33,516,481.17$. When monetary costs were subtracted from benefits, the metropolitan area realized a net monetary benefit of $\$ 5,643,347.37$.

\section{DISCUSSION}

A study of the impact of tourism on a metropolitan economy should address such important issues as the income and employment multiplier effects, the monetary benefits and costs associated with tourism. But as indicated earlier, most research on this subject has dealt with the assessment of income and employment multiplier effects only. This leaves the question of whether or not tourism pays for itself unanswered. The methodology offered here addresses 
this important issue by specifically measuring the monetary benefits and costs due to tourism in the Portland metropolitan area. It also provides a statistically sound analytical model for assessing the total impact of tourism on a metropolitan economy.

In general, this analysis has yielded results which support the importance of tourism to the Portland metropolitan economy during the period covered.

Empirical tests relating to the first hypothesis showed that of the total tourist expenditures in the area, only 53 percent remained in the metropolitan area as income. Also, of full-time equivalent jobs resulting from the tourist spending, 64 percent remained in the area. The question could be asked: "Why was the percent of tourist spending that remained in the area as income not equal to the percent of tourism-generated jobs that remained in the area?" The basic reason for the difference is that some tourism-related businesses are very labor intensive, while others are not. Equal amounts of spending in various sectors might not create equal jobs. For example, although lodging establishments and gasoline service stations respectively accounted for 23 and 20 percent of the total tourist spending in $1980,3,116$ jobs were directly created in lodging establishments while only 619 jobs were directly created in the gasoline service stations (see Table 4). In monetary terms, one worker was hired for every $\$ 24,470.76$ spent in lodging establishments whereas, for every 
$\$ 107,093.84$ spent in gasoline service stations one worker was hired - a ratio of 1:4. This finding compared very closely with that reported by Bird and Miller (1962), in their study of Ozarks, Missouri. Furthermore, in the cases of gasoline service stations and movie theatres, the majority of the wholesale firms supplying them were not located within the metropolitan area, thereby resulting in sizable leakages in the economy.

Leakages are evident in the tourism-generated employment in those business categories that remained in the metropolitan area. For example, during the period covered, 81 percent of tourism-generated jobs in lodging establishments remained in the metropolitan area, while in gasoline service stations and movie theatres, only 32 percent and 15 percent respectively of tourism-generated jobs remained in the area (see Table V). Capital-intensive business categories e.g. gasoline service stations and movie theatres, contributed to more leakages in the metropolitan economy than the labor-intensive business categories. In a period of high unemployment with tight government budgets, the tourism-generated employment in these labor-intensive business categories, has proven to be of significant benefit to the metropolitan area, especially in relation to indirect property taxes from these jobs.

Regarding the second hypothesis on moretary benefits and costs, analytical findings indicated that tourismgenerated revenues per tourist person-day were \$2.26, and 
metropolitan service costs per tourist person-day were \$1.88. Comparing metropolitan service costs with revenues, there was a net monetary benefit of 38 cents -- approximately a 20 percent margin. Given the way the monetary benefit-cost model is set up, this margin seems relatively small. But as indicated in the last chapter, this study applied some elements of self-report survey research method. Normally, selï-report survey research is subject to a degree of specification error. Some data applied in the monetary benefit-cost model have these same problems in common with other analytical models that apply survey research. Difficulties in resolving such problematic issues may very well be exacerbated when gathering information that demands accuracy of memory recall. Such has proven to be the case in this study. Also, in Chapter IV, the assumptions and arguments for estimation of the parameters pertinent to the resarch models were presented. Some of those assumptions have some inherent problems which may lead to a specification error. Therefore, the monetary benefit-cost model applied in this study may still have a specification error that cannot be eliminated at the moment. But by and large, this error should have been offset by other important data applicable to the model, e.g., revenues returned to the metropolitan area that were derived through personal and corporate income taxes. For obvious reasons, these revenue sources are not accessible in this study. It is evident that had these revenues been included in the analysis, the 
net monetary benefits would have been greater than 38 cents. The intention here is not to overemphasize the importance of these revenue sources, but to indicate that they are a factor.

Many states have a consumer sales tax. Thus, it was thought reasonable to explore the tourism-generated revenues that would have accrued to the metropolitan area had there been a consumer sales tax in Oregon, assuming a six-cents per-dollar tax as applied in Washington state. Were this tax in effect, tourist spending of $\$ 331,500,900.90$ as reported in Chapter IV, would have yielded $(\$ 331,500.900 .90$ $\mathrm{X}$ 0.06), $\$ 19,890,054.05$. Normally, this tax is collected by the state and later returned to the county and the incorporated areas or cities within the county according to two formulas used statewide in Washington. That is, of the six cents local sales tax per dollar, 83.5 percent is returned to the city, 15 percent is returned to the county and 1.5 percent stays with the state. Also, of the six-cents-taxper-dollar of spending collected in uncorporated area, 98.5 percent is returned to the county government, and 1.5 percent stays with the state. If the state of Oregon were to apply these formulas, the direct tourism-generated sales tax revenues in the metropolitan area would have been significant $(\$ 19,890,054.05 \times 0.985=\$ 19,591,703.24)$ during the study period.

However, it is important to speculate that in a country where there are states without consumer sales tax in 
effect, this type of taxation could have both positive or negative impacts on a metropolitan economy. The positive impact would be in the form of more tax revenues due to tourist spending in the area. One negative impact might be in the form of reduced revenues due to fewer tourists and lower spending in the area. That is, such sales tax might discourage visitors to the area, and potential tourists might decide not to spend much of their money in the state. This speculation does not have strong applications in the United States since Oregon and New Hampshire are the only states without a consumer sales tax. Nonetheless, the impact of consumer sales tax on tourist flow, patterns and volume of tourist spending is not the thrust of this dissertation and will not be discussed further here. In the secondary data sources section of Chapter III, it was noted that there were no uniform gasoline and room occupation tax rates in the tri-county area. Clackamas and Multnomah counties had room occupation tax rates of 6 percent, and Washington county had 5 percent. Clackamas county had no gasoline tax; Multnomah had a three cents tax on every gallon of gasoline sold, and Washington county had a one-cent-per-gallon tax. This disparity in tax rates may encourage more spending in some areas of the metropolitan area and less in others. Business proprietors might benefit from increased sales even though the metropolitan area in general may not benefit much in terms of tax revenues. 
The data collection process revealed a problem common to United States metropolitan areas of the size of Portland. This problem relates to the absence of a central agency responsible for research and data collection, planning, communications, and tourism promotion in the Portland metropolitan area. The Greater Portland Convention and Visitors Bureau has not been particularly effective in carrying out its responsibilities, whatever the reasons. Hence, tourism development policies in the metropolitan area have been inconsistent. Instead of the counties working together through a single agency, e.g., the Greater Portland Convention and Visitors Bureau, to promote tourism in the area, they have been trying to carry out individual tourism promotion programs. For example, on May 16, 1982, Washington County placed a job advertisement in the Oregonian for an Economic Development Coordinator, whose responsibilities would include:

Coordination of an economic development program to promote tourism and use of facilities within the county. Working with the local jurisdiction, businesses, citizens and developers to attract new businesses and promote tourism in the county ....

Although this job has not been filled yet, it is evidence of the lack of a coordinated tourism development program in the metropolitan area.

This study therefore suggests that there is need for the organization of a long-range tourism planning committee in the metropolitan area which would be responsible for 
developing a comprehensive plan for tourism development in the area. The committee should give attention to the continuing tourism development needs of the area within a future scope of three to five years. Such committee should therefore be charged with the responsibility to:

- collect the necessary information relative to the present situation of the metropolitan area as it relates to tourism.

- recommend long range goals and objectives to the area.

- evaluate the long-range effectiveness of tourism in the area.

The committee should establish and maintain close working relationships with the service organization and elected officials in the area by reporting and interpreting longrange goals and objectives to appropriate groups.

Merits of the Study

The methodologies developed in this research to measure the economic impact of tourism are straightforward, standard, and easy to apply. The study could be easily used by planning departments, the Chamber of Commerce, the City Council, and developmental agencies in any metropolitan area. In periods of continued inflation and unemployment, with consequent strain on metropolitan governments' budgets, metropolitan department heads and elected officials need to be aware of public monetary costs associated with industrial developments in the area, rezonings and annexations, and other land use plans. Based on such knowledge, they could 
project the resident and school-age children populations due to such developments, or the number of public employees, e.g., police, firemen, etc., to be hired over time. The analytical procedures covered in this study provide metropolitan elected officials, local staff planners, city managers, business administrators, and private consultants a method and information they might need to make such decisions.

This study is the first attempt at a comprehensive documentation of the significance of tourism to the area economy. It produces base-line data that will be of assistance in future economic development planning in the metropolitan area. Apart from its potential use, it provides a third party analysis of the effect of tourism on the metropolitan economy.

This work can serve as a guide to the way in which tourist impact analysis, at least in relation to service costs and tax revenues, is conducted. In producing a comprehensive methodology for tourist impact analysis, this work establishes a set of criteria for assessment of service costs and tax revenues attributable to tourism. The study has been presented in the expectation that the insight and knowledge gained about tourism in the metropolitan area will help other areas realize the full potential of the tourism industry. Many of the research problems encountered and techniques developed are likely to be applicable for other areas where the industry has not been fully realized. 
Cities in Third World countries, e.g., Nigeria, Ghana, Sierra Leone, etc., might particularly be aided through the use of the methods and techniques developed in this study to answer some of the many questions regarding the needs, planning, and opportunities in the tourism industry. Besides, monetary benefit-cost considerations can also be legally used within the confines of numerous planning or planning- related topics. Since economy and efficiency have long been basic goals and objectives of planning and economic development, monetary benefit-cost analysis as developed in this study can be applied to achieve these goals.

Limitations of the Study

A major limitation of the study is the time period covered and the availability of data used in the impact analysis. No agency keeps an up-to-date record of the flow and volume of tourist spending in the metropolitan area. The State Department of Transportation, which reports such data statewide, does not conduct a tourist survey every year. Thus, a comparison of the 1980 flow and volume of tourist spending in the area with that of 1979 or 1981 while, theoretically interesting, was practically not possible.

Again, the analysis relied on the state input-output table in the derivation of the percent of metropolitan income that was spent in the area, and the percent of goods and services sold locally that were produced locally. This 
was because, at present, there are no input-output studies for the metropolitan area. In the derivation of these indices, the following assumptions were made:

(a) the production processes were invariant among regions of the state including the metropolitan area.

(b) industry mixes within the sectors in the state were similar to those in the metropolitan area.

(c) the percent of sales to final demand sectors contained in the state table was the same in the area, for each industrial sector.

These assumptions might be weakened because production processes and industry mixes in some rural and agricultural counties in the state might not be the same as in Clackamas, Multnomah, and Washington counties. Also, the state inputoutput study as reported by Watson and Allen (1965), is fairly old, so there is need for a new input-output study for the state. It may have been better to apply an inputoutput study of the localized area in the analysis, had that been possible. Limited resources precluded doing so. Though some adjustments have been made in the income and employment multiplier models, there may still be a specification error that cannot be eliminated at the moment. An additional possible limitation is an assumption that might lead to underestimation of tourist spending in the metropolitan area. In Chapter III, a statement was made that the percent of tourists who visited the metropolitan 
area in 1980 was assumed to be roughly comparable to the percent of tourist person-days and total spending in the area. On the other hand, critics allege that Oregon tourists spend more money in the Portiana hetropolitan area than in any other Oregon community. By the nature of the data available in this analysis, there is no statistical method at present to verify this allegation. Therefore, it is reasonable in this first analysis to assume that the percent of tourists that visited the metropolitan area in 1980 is roughly comparable to the proportion of tourist person-days and total spending. In spite of the above Iimitations, the methodologies as applied in this research are reliable and can be applied to any annual data set.

\section{CONCLUSIONS}

Two major conclusions can be drawn from this study. First, there are more monetary benefits in terms of tax revenues from tourism than there are service costs to the metropolitan area. This is supported by the evidence that a net monetary revenues of $\$ 5.6$ million attributable to tourism was realized in the metropolitan area during the period covered. Based on these findings, it is evident that the assertion by critics that the metropolitan taxpayer might be subsidizing the tourism industry is unfounded. Again, there is significant employment creation and income generation due to tourist expenditures in the area. This is supported by the finding that the tourism income and 
employment multipliers in the area are 1.1024. Finally, as indicated earlier, previous studies on the impact of tourism on metropolitan economies focused on income and employment multiplier effects only. The methodology as offered in this dissertation has taken the tourism impact analysis one step further by specifically measuring the monetary benefits and costs associated with tourism in the metropolitan area. By examining this unexplored aspect of the economic impact of tourism, the methodology as developed here is an improvement on tourism economic impact assessment literature.

\section{Future Research}

During the course of this study, a number of issues were raised and unexplored gounds were noted for future exploratory research. First, as indicated in the discussion section of this chapter, the Federal and State income taxes paid by the tourist-related businesses and tourism-generated employment in the area were not included in the analysis. Obviously, if these revenue sources had been included, the net monetary benefits due to tourism would have been higher than currently analyzed. Since these data are not public record and therefore could not be released, a means of obtaining them is suggested for future exploratory research.

The impact of consumer sales tax on tourist flow, pattern and volume of spending is also suggsted as an area for future research. In Chapter III, the study alleged that Oregon tourists spend more money in the Portland 
metropolitan area than in any other Oregon community. This allegation cannot currently be verified. Hence,this unresolved issue is suggested for future exploratory studies.

Finally, in Chapter IV, there was an extensive discussion of how to precisely apportion the tourist- and resident-generated public parking revenues. Development of a more precise method than presented in this study is suggested as an area for future research. 


\section{BIBLIOGRAPHY}

Alden, Jeremy and Morgan, Robert. Regional Planning: A Comprehensive View, New York: John Wiley and Sons, 1974.

Allen, Robert I. and Watson, Donald A. The Structure of the Oregon Economy: an Input/Output Study, Eugene, Oregon: University of Oregon Press, 1965.

Andrews, Richard. "Mechanics of Urban Economic Base," Land Economics, Madison, Wisconsin: University of Wisconsin Press, August 1954, pp. 260-269.

Archer, B.H. The Impact of Tourism Upon Regional Economies, Lond on, England: Local Government Finance, Number 6, December 1971.

Archer, B.H. and Owen, Christine B. "Towards a Tourist Regional Multiplier," Journal of Regional Studies, United Kingdom: Pergamon Press, Volume 5, Number 4, 1971, pp. 289-294.

Archer, Brian. The Impact of Domestic Tourism, London, England: Bangor Occasional Papers in Economics, Number 2, 1973.

Baker, Doug - Guide to Portland, Forest Grove, Oregon: Times Litho Print, 1965.

Bannon, Joseph J. Leisure Resources: Its Comprehensive Planning, Englewood Clifŕs, New Jersey: Prentice Hall, Incorporated, 1976.

Beekhuis, Jeanne. "Tourism as a Tool for Economic Development," Environmental Comment, Washington D.C.: The Urban Land Institute, January 1981, pp. 8-10.

Bendavid, Avrom. Regional Economic Analysis for Practioners, New York: Preager, Special Studies in International Economics and Development, 1974.

Bird, Ronald and Miller, Frank. Contributions of Tourist Trade to Incomes of People in Missouri Ozarks, Columbia, Missouri: University of Missouri Press, College of Agriculture Research Bulletin, Number 799, 1962 .

Bish, Robert L. and Nourse, Hugh, 0. Urban Economics and Policy Analysis, New York: McGraw-Hill Book Company, 1975 . 
Bryden, John M. Tourism and Development: A Case Study of the Commonwealth Carribean, Cambridge, England: The Cambridge University Press, 1973.

Burchell, Robert $W$. and Listokin, David. The Fiscal Impact Handbook, New Brunswick, New Jersey: The Center For Urban Policy Research, 1980.

Burchell, Robert W. and Listokin, David. Practioner's Guide to Fiscal Impact Analysis, New Brunswick, New Jersey: The Center For Urban Policy Research, 1980.

Burton, Thomas L. and Noad, P.A. Recreation Research Methods: A Review of Recent Studies, Birmingham, United Kingdom: University of Birmingham Press, Center For Urban and Regional Studies, Occasional Paper, Number 3, 1968.

Child, John. The Basic Study on The Impact of Visitor Dollars in Hawaii, Honolulu: John Child and Company, 1953 .

City of Cambridge Planning Department. Tourism in Cambridge, England: City of Cambridge, 1978.

Clackamas County. Budget Revenue Records Accounts Status Report 1980-81, Oregon City: Clackamas County, 1981 .

Clackamas County. Statement of Taxes Levied in Clackamas County, Oregon for Year Ending June 30, 1981 , Assessment Roll of 1980, Oregon City: Clackamas County, 1981.

Clawson, Marion. Methods of Measuring The Demand For and Volume of outdoor Recreation, Washington D.C.: Resource For The Future Incorporated, Reprint Number 10, 1959.

Clawson, Marion and Knetsch, Jack L. Economics of Outdoor Recreation, Baltimore: The John Hopkins Press, 1966.

Clement, Harry G. The Future of Tourism in The Pacific and Far East, Washington D.C.: Checchi and Company, 1961.

Clement, Marvin et al. The Impact of Travel on The Oregon Economy and Visitor Use of Tourist Serving Facilities, Richland, Washington: Battele Pacific Northwest Laboratories, 1973.

Craig, Paul G. Futire Growth of Hawaiian Tourism, Honolulu, Hawail: (Unpublished), Ph.D. Thesis, 1963. 
Czamanski, Stanislaw. "Applicability and Limitations in The The Use of National Input-Output Tables For Regional Studies," Regional Science Association Papers, Philadelphia, Pennsylvania: The Regional Science Association, Volume 23, 1969, pp. 65-80.

De Rooy, Jacob. "Analysis of Public Employment Impact Multipliers in Depressed Areas," Growth and Change, A Journal of Regional Development, Lexington, Kentucky: University of Kentucky Press, Volume 8, Number 3, July 1977, pp. 42-46.

Dean, Gilian et al. "The Local Economic Impact of State Parks," Journal of Leisure Research, Washington D.C.: The National Recreation and Park Association, Volume 10, Number 2, 1978, pp. 98-112.

Dean, Joel. Managerial Economics, Englewood Cliffs, New Jersey: Prentice-Hall, Incorporated, 1951.

Diamond, Peter A. "The Economics of Tourism," Nairobi, Kenya: Discussion Paper, Number 76, (Unpublished), January 1969.

Durden, Garey C. "Toward a Method of Determining The Impact of Tourist Expenditures on State Tax Revenues," The Annals of Regional Science, A Journal of Urban, Regional and Environmental Research and Policy, Bellingham, Washington: Union Printing Company, Volume 12, Number 2, July 1978, pp. 72-82.

Economic Commission for Europe. Planning and Development of The Tourist Indusiry in the E.C.E. Region, New York: United Nations, 1976.

Economist Intelligence Unit. "The Role of Tourism in Economic Development, Is It a Benefit or a Burden?" International Tourism Quarterly, London, England: The Economist Intelligence Unit, Number 2, 1973, pp. 53-68.

English Tourist Board. Planning For Tourism in England: A Planning Advisory Note, London, England: (Unpublished), 1978 .

Florida Development Commission Staff. 1965 Tourist Study, Tallahassee, Florida: State Government Press, 1966.

Gamble, H.B. "Community Income From Outdoor Recreation: Ocean City, Maryland," A Paper Presented to The Governor of Maryland's Recreatjon Conference, (Unpublished), 1965. 
Gardener, John L. Local Employment Multipliers and Regional Growth, Springfield, Virginia: National Technical Information Service, 1972.

Garrison, Charles B. "A Case Study of The Local Economic Impact of Reservoir Recreation," Journal of Leisure Research, Washington D.C.: The National Recreation and Park Association, Volume 6, Number 1, Winter 1974, pp. 7-19.

Garrison, Charles B. "The Impact of New Industry: An Application of The Economic Base Multiplier to Small Areas," Land Economics, Madison, Wisconsin: University of Wisconsin Press, Volume 48, Number 4, November 1972 , pp. 239-337.

Ghali, Moheb A. "Tourism and Economic Growth: An Empirical Study," Economic Development and Cultural Change, Lond on, England: Number 3, April 1976, pp. 527-531.

Goeke, Patricia (Editor). Creating Economic Growth and Jobs Through Travel and Tourism, Washington D.C.:U.S. Government Printing Office, 1981.

Governor's Economic Recovery Task Force. Governor's Economic Recovery Council Report, Salem, Oregon: State Government Printing Press, 1982.

Hamilton, John G. et al. International Tourism, London, United Kingdom: The Economist Intelligence Unit Limited, Quarterly Economic Review, Special Number 7, 1970 .

Hannigan, Scott. Tourism: Its Role in The Cascade Locks, Uregon, Fortiand, Uregon: Portland State University TUrban Studies Center) Press, 1970.

Hansen, Lee W. and Tiebout, Charles M. "An Intersectoral Flows Analysis of The California Economy, "The Review of Economics and Statistics, Cambridge, Massachusetts: Harvard University Press, Volume XLV, Number 4, November 1963, pp. 409-418.

Hawley, James $R$. The Travel Industry, Its Role in The Economy of Coos County, Oregon, Portland, Oregon : Portland State University (Urban Studies Center) Press, 1970.

Heilbrun, James. Urban Economics and Public Policy, New York: st. Martin's Press, 1981.

Helly, Walter. Urban Systems Model, New York: Academic Press, 1975 . 
Hewings, G.J.D. "Regional Input-Output Models in the U.K.: Some Problems and Prospects For The Use of Nonsurvey Techniques," Regional Studies, Journal of The Regional Studies Association, Great Britain: Pergamon Press Limited, Volume 5, Number 1, April 1971, pp. 11-22.

Hildebrand, George H. and Mace, Arthur Jr. "The Employment Multiplier in an Expanding Industrial Market: Los Angeles County, 1940-47," The Review of Economics and Statistics, Cambridge, Massachusetts: Harvard University Press, Volume 32, Number 3, August 1950, pp. 241-249.

Hinkson, Charles E. Traveler Profiles, A Study of Summer Travel to Alaska During 1963 and 1964, Juneau, Alaska: State Department of Economic Development and Planring, 1964 .

Influential Contacts Limited. Contacts Influential: Portland, Oregon 1980-81, Commerce and Industry Directory, Portland, Oregon: Influential Contacts Limited, 1980.

Isard, Walter. Methods of Regional Analysis: An lritroduction to Regional Science, New York: The Technology Press of M.I.T., Massachusetts and John Wiley and Sons Inc., 1960 .

Isard, Walter and Langford, Thomas W. Regional InputOutput Study: Recollections, Reflections, and Diverse Notes on The Philadelphia Experience, Cambridge, Massachusetts: The Massachusetts Institute of Technology Press, Regional Science Studies Series, Number 10, 1971.

Johnson, Fred. "A Pragmatic Methodology For Measuring Fiscal Impacts of Industrial Location," The Review of Regional Studies, Journal of Southern Regional Science Association, Birmingham, Alabama: University of Alabama Press, Supplement, 1974, pp. 67-76.

Jonish, James E. and Peterson, Richard E. "The Impact of Tourism: Hawaii," Cornel1 Hotel and Restaurant Administration Quarterly, Ithaca, New York: Cornell University Press, Volume 14, Number 2, August 1973, pp. 5-12.

Judd, Dennis R. The Politics of American Cities: Private Power and Public Policy, Boston, Massachusetts: Little, Brown and Company, 1979. 
Katler, Robert J. and Lord, William B. "Measurement of The Impact of Recreational Investments on a Local Economy," American Journal of Agricultural Economics, Menasha, Wisconsin: American Agricultural Economics Association, Volume 50 , Number 2, May 1968, pp. 243257 .

Kelleher, Richard M. "The Impact of Tip Credit Repeal," The Cornell Hotel and Restaurant Administration Quarterly, Ithaca, New York: Cornell University Press, Volume 17, Number 1, May 1976, pp. 10-14.

Kite, Rodney and Schutz, William. The Economic Impact on Southwestern Wyoming of Recreationists Visiting Flaming Gorge Reservoir, Laramie, Wyoming: University of Wyoming, Agricultural Experiment Station, 1967.

Knetsch, Jack L. and Turgut, Var. "The Impacts of Tourism and Recreation Development," The Tourist Review, London, England: International Association of Scientific Experts in Tourism, Number 4, 1976, pp. 59.

Lavery, Patrick (Editor). Recreational Geography, New York: Halated Press, A Division of John Wiley and Sons Incorporated, 1974 .

Leven, Charles L. "Regional and Interregional Accounts in Perspective," Regional Science Association Papers, Philadelphia, Pennsylvania: The Regional Science Association, Volume 13, 1964, pp. 127-144.

Lewis, Cris W. "Export Base Theory and Multiplier Estimation: A Critique," The Annals of Regional Scierce, Bellingham, Washington: Union Printing Company, Vclume 12, Number 2, July 1976, pp. 58-70.

Lichfield, Nathaniel. "Cost Benefit Analysis in Urban Development - A Case Study: Swanley," The Regional Science Association Papers, Philadelphia, Pennsylvania: The Regional Science Association, Volume 16, 1966, pp. 129-153.

Little, Arthur D. Tourism and Recreation: A State of the Art Study, Washington D.C.: United States Government Printing Office, 1967.

Lloyd, Peters and Dicken, Peters. Location in Space: A Theoretical Approach to Economic Geography, New York: Harper and Row Publishers, 1977.

Lundberg, Donald E. The Tourist Business, Chicago: Institutions/Volume Feeding Management Magazine, 1973. 
MacCannell, Dean. The Tourist: A New Theory of The Leisure Class, New York: Schocken Books, 1976.

Martin, Thomas. "Economic Needs: Factors That Influence Investment," Environmental Comment, Washington D.C.: The Urban Land Institute, Eecember 1981, pp. 7-8.

Masser, Ian. Analytical Models For Urban and Regional Planning, Newton Abbot, U.K.: David and Charles (Publishers) Limited, 1972.

McConnell, Campbell R. Economics: Principles, Problems and Policies, New York: McGraw-Hill Book Company, 1975.

McIntosh, Robert W. "Some Tourism Economics," Cornell Hotel and Restaurant Administration Quarterly, Ithaca, New York: Cornell University Press, Volume 14, Number 2, August 1973, pp. 2-4.

Miernyk, William $H$. The Elements of Input-Output Analysis, New York: Random Holise, Inc., 1966.

Moody, Harold T. "The Empirical Verification of The Urban Base Multiplier: Traditicnal and Adjustment Process Models," Land Economics, Madison: University of Wisconsin Press, Volume 46, Number 1, February 1970, pp. $91-98$.

Moore, Arthur L. Reservior Recreation and Local Economic Growth: Economic Studies of Outdoor Recreation, Washington D.C.: United States Government Printing Office, Outdoor Recreation Resources Review Commission Study Report, Number 24, 1962.

Moore, Fredrick T. and Peterson, James W. "Regional Analysis: An Interindustry Model of Utah," The Review of Econoomics and Statistics, New York: Kraus Reprint Corporation, Volume $37,1955, \mathrm{pp}$. 368-383.

Multnomah County, Tax Supervising and Conservation Commission. 1980-81 Annual Report, Portland: Multnomah County 1981 .

Multnomah County. Independent Audit Repori for the Cities and County 1980-81, Portland: Multnomah County, 1981.

New Hampshire Department of Resources and Economic Development. Economic Impact of Recreation, Vacation and Travel on New Hampshire, Concord: State Government Printing Press, 1962. 
O'Donnell, Edward T. An Assay on Method of Measurement of

Employment Directly Generated by Tourism in

- Massachusetts 1958-1967, Regional Office, Bureau of Labor Statistics, U.S. Department of Labor, Boston: United States Government Printing Office, 1968.

Oregon State Department of Human Resources, Employment Division, Research and Statistics Section. Oregon Covered Employment and Payrolls by Industry and County 1979, Salem State Government Printing Press, 1981.

Oregon State Department of Transportation, Highway Division, Accounts Section. "Gasoline Tax Revenues: City and County Apportionment Report, Fiscal Year 1980-81," Salem: (Computer Print Out).

Oregon State Department of Transportation, Travel Information Section. "1980 Out-of-State Travel Revenue Report," Salem: Government Printing Press, No Date.

Oregon State Department of Transportation, Travel Information Section. "1980 Tourist Interview Survey," Salem: Government Printing Press, No Date.

Oregon State Department of Transportation, Travel Information Section. "1980 Advertising Conversion Study," Salem: State Government Printing Press, No Date.

Oregon State Legislative Assembly, Legislative Counsel Committee, Oregon Revised Statues Volume 8, Annotations (1981 Cumulative Supplement), Salem: State Government Printing Press, 1981.

The Oregonian Staff. "Classified Advertisement," Portland: The Oregonian Publishing Company, May 16, 1982, pp. D.32.

Organization For Economic Cooperation and Development. Tourism Development and Economic Growth, Estoril, Portugal: Seminar Held Under The Auspices of The Technical Assistance Program of The O.E.C.D., May 1966.

Organization For Economic Cooperation and Development. The Impact of Tourism on The Environment, Paris, France: O.E.C.D. General Report, 1980.

Peters, Michael. International Tourism, New York: Hutchinson and Company Limited, 1969. 
Peterson, Richard S. and Tiebout, Charles M. "Mesasuring The Impact of Regional Defense - Space Expenditures," The Review of Economics and Statistics, Cambridge, Massachusetts: Harvard university Press, Volume XLVI, Number 4, November 1964, pp. 421-428.

Pfouts, Ralph W. (Editor). The Techniques of Urban Economic Analysis, Trenton, New Jersey: Chander-Davis Publishing Company, 1960.

Pleeter, Saul (Editor). Economic Impact Analysis: Methodology and Applications, Studies in Applied Regional Science, Number 9, Boston, Massachusetts: Martinus Nijhoff Publishing, 1980.

Prest, A.R. and Turvey R. "Cost-Benefit Analysis: A Survey," The Economic Journal, London: MacMillan (Journals) Limited, Volume LXXV, Number 300, December 1965, pp. $683-735$.

Rifkind, Carole. "Cultural Tourism: A New Opportunity For The Industrial City?", Environmental Comment, Washington D.C.: The Urban Land Institute, January 1981, pp. 4-7.

Rifkind, Carole. "The Prospects For Regional Tourism Development in New England," Environmental Comment, Washington D.C.: The Urban Land Institute, December 1981 , pp. 4-6.

Robb, James F. "Economic Impact of The Portland Rose Festival: 1981 Update," Portland, Oregon: Pacific Research, Incorporated (Unpublished Report), December 1981 .

Robinson, H. A Geography of Tourism, London: MacDonald and Evans Limited, 1976.

Rovelstad, James W. Analytical Measures of Travel For States and Smaller Areas, Bureau of Business Research, College of Business and Economics, Morgan Town: West Virginia University Pres:s, 1977.

Rovelstad, James W. "Implementing Tourism: The Role of The Community," Environmental Comment, Washington D.C. The Urban Land Institute, January 1981, pp. 11-14.

Samuelson, Paul A. Economics, New York: McGraw-Hill Book Company, 1970 .

Spencer, Milton H. Contemporary Economics, New York: Worth Publishers, Inc. 1974 . 
Taylor, Peter J. Quantitative Methods in Geography, Boston, Massachusetts: Houghton Mifflin Company, 1977.

Thompson, Gerald E. "An Investigation of The Local Employment Multiplier," Review of Economics and Statistics, Cambridge, Massachusetts: Harvard University Press, Volume 41, Number 1, February 1959, pp. 61-67.

Thompson, Wilbur R. A Preface to Urban Economics, Baltimore, Maryland: The John Hopkins Press, 1968.

Tiebout, Charles M. The Community Economic Base Study, New York: Committee For Economic Development, Supplemtary Paper, Number 16, 1962.

Tiebout, Charles M. "Input-Output and The Firm: A Technique For Using National and Regional Tables," The Review of Economics and Statistics, Cambridge, Massachusetts: Harvard University Press, Volume 49, Number 2, May 1967, pp. 260-262.

Torkelson, David R. et al. A Study of The Vacation and Recreation Industry in North Dakota to Determine Opportunities For Small Business, Fargo, North Dakota: North Dakota State University of Agriculture and Applied Sciences Press, Engineering Experiment Station Series, Number 7, 1963.

United States Department of Commerce, Bureau of The Census. Census of Population, Number of Inhabitants: Oregon, Washington D.C.: U.S. Government Printing Office, December 1981 .

United States Department of Commerce, Bureau of The Census. Census of Service Industries, Washington D.C.: U.S. Government Printing Office, Volume II, Geographic Area Statistics, Part 3, August 1981.

United States Department of Commerce, Bureau of Economic Analysis. Local Area Personal Income 1974-79: Far West Region, Including Alaska and Hawaii, Washington D.C.: U.S. Government Printing Office, Volume 9, June 1981.

United States Department of Commerce, Bureau of The Census. 1977 Oregon Census of Retail Trade: Major Retail Centers in S.M.S.A., Washington D.C.: U.S. Government Printing Office, February 1980.

United States Department of Commerce, Bureau of The Census, Statistical Abstract of The United States: 1981, Washington D.C.: U.S. Government Printing Office, December 1981. 
United States Department of Commerce. Your Community Can Profit From The Tourist Business, Washington D.C.: U.S. Government Printing Office, 1957.

United States Department of Labor, Bureau of Labor Statistics, "News U.S. Department of Labor, Consumer Price Index - Urban (C.P.I.-U), 1977," Washinton D.C.: U.S. Government Printing Office, 1977.

United States Department of Labor, Bureau of Labor Statistics," News U.S. Department of Labor, Consumer Price Index - Urban (C.P.I.-U), 1980," Washington D.C.: U.S. Government Printing Office, 1980.

Wahab, Salah-Eldin Abel. Elements of Macro-Planning in Tourism Development, Lond on, United Kingdom: International Association of Scientific Experts in Tourism, The Tourist Review, Number 2, 1973.

Washington County. Finance Accounts Receivable Report 1980-81, Hillsboro: Washington County, 1981.

Washington County. Summary Assessment and Tax Roll 1980, Hillsboro: Wahsington County, 1981.

Weaver, Glenn D. et al. "Appraising Tourism Potential," Tourism USA, Columbia: University of Missouri Press, Volume 1, 1978, pp. 1-20.

Weaver, Glenn D. et al. "Assessing Your Product and The Market," Tourism USA, Columbia: University of Missouri Press, Volume II, 1978, pp. 1-84.

Weaver, Glenn D. et al. "Marketing Tourism," Tourism USA, Columbia: University of Missouri Press, Volume III, 1978, pp. 1-27.

Weaver, Glenn D. et al. "Sources of Assistance," Tourism USA, Columbia: University of Missouri Press, Volume IV, 1978, pp. 1-27.

Williams, Harry B. "Wages and Tips in Hotels and Motels," Monthly Labor Review, Washington D.C.: U.S. Government Printing Office, March 1975, pp. 60-63.

Wilson, Holton J. "Impact Analysis and Multiplier Specification," Growth and Change, A Journal of Regional Development, Lexington, Kentucky: University of Kentucky Press, Volume 8, Number 3, July 1977, pp. $42-46$. 
Wolk, Dana and Nix, James. "Paid Vacation Provisions in Collective Agreements 1952," Monthly Labor Review, U.S. Government Printing office, August 1952, pp. 162167.

Young, George. Tourism: Blessing or Blight? Baltimore, Maryland: Penguin Books Incorporated, 1973. 


\section{APPENDIX A}

QUESTIONNAIRES USED IN SURVEYS OF HOTELS AND MOTELS

Instructions: Some of these questions require a simple check $(\checkmark)$, a short answer $(s)$ or are self-explanatory. Notice that the information asked is for the year 1980. Where specific figures are asked for, provide them as accurately as you can, but please do not leave them blank even if you have to estimate. The questions regarding guests apply only to those guests that spent at least 24 hours in your motel or hotel.

1. Please check ( $r$ ) the line that best describes your business.
(a) Hotel $\ldots \ldots \ldots$......
(b) Motel $\ldots \ldots \ldots$.

2. Consider your total sales in 1980 (lodging, food and drink if served) as coming from two types of guests; guests from outside the Portland metropolitan area and guests from within the metropolitan area. Please estimate as closely as you can the percent of your sales from these two groups.

(a) Percent sales from guests outside the metropolitan area $\ldots \ldots \ldots \%$

(b) Percent sales from guests within the metropolitan area

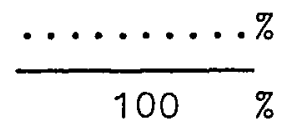

3. Your total supply of goods and services in 1980 may 
have come from two groups of producers (those within the Portland metropolitan area and those outside the area, or entirely from one. Estimate as closely as you can the percent of your purchases from these two groups.

(a) Percent of purchases from producers outside the metropolitan area $\quad \ldots \ldots \ldots \ldots$

(b) Percent of purchases from producers within the metropolitan area $\quad \ldots \ldots \ldots \%$ $100 \%$

4. In order to get an idea of the size of the business covered by this questionnaire, please indicate in terms of full time person-week, the number of people you employ

5. Of the number in question 4, how many fall into the following categories:
(a) White Male
(b) White Female
(c) Nonwhite Male
(d) Nonwhite Female ...... 


\section{APPENDIX B}

QUESTIONNAIRES USED IN SURVEYS OF EATING AND DRINKING ESTABLISHMENTS, GASOLINE SERVICE STATIONS, MOVIE THEATRES AND MISCELLANEOUS RETAIL STORES

Instructions: some of these questions require short answer(s) or are self-explanatory. Notice that the information asked is for the year 1980. Where specific figures are asked for, provide them as accurately as you can, but please do not leave them blank even if you have to estimate.

1. Please check $(\checkmark)$ the line that best describes your business.

(a) Eating-Drinking Establishments

(b) Gasoline Service Stations

(c) Movie Theatres

(d) Gift Shops

(e) Sporting Goods Shops

(f) Other (specify)

2. First consider your total sales for 1980 as coming from two types of customers -- tourists or visitors to the metropolitan area and nontourists or residents of the Portland metropolitan area. Estimate your percent sales to these two groups:
(a) Percent sales from tourists
$\ldots \ldots \ldots \%$
(b) Percent sales from nontourists

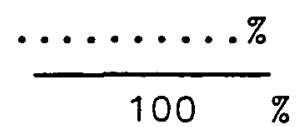


3. Your total supply of goods and services in 1980 may have come from two groups of producers (those within the Portland metropolitan area and those outside the area), or entirely from one. Estimate as closely as you can the percent of your purchases from these two groups.

(a) Percent of purchases from producers outside the metropolitan area $\quad \ldots \ldots \ldots \%$

(b) Percent of purchases from producers within the metropolitan area

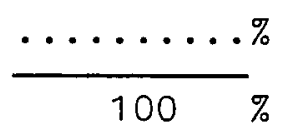

4. In order to get an idea of the size of the business covered by this questionnaire, please indicate in terms of full time person-week, the number of people you employ

5. Of the number in question 4, how many fall into the following categories:
(a) White Male
(b) White Female
(c) Nonwhite Male
(d) Nonwhite Female ...... 
APPENDIX C

QUESTIONNAIRES USED IN SURVEYS OF HOTEL

AND EATING-DRINKING ESTABLISHMENTS' MANAGERS ON TIPS

Instructions: Some of these questions require a simple check $(\sim)$, a short answer(s) or are self-explanatory. Where specific figures are required, provide them as accurately as you can, but please do not leave them blank even if you have to estimate.

When customers eat or drink in your hotel, restaurant or tavern, they normally leave some tips, in return for services well done.

1. Between 1975 and 1980, do you think that the tip rate by customers has declined, unchanged or increased? Please check ( $\sim$ ) the space that best describes the situation in your personal opinion.
(a) Declined
(b) Unchanged $\ldots \ldots \ldots \ldots$
(c) Increased

2. If the tip rate has changed, by how much percent?

Answer $\ldots \ldots \ldots \ldots \ldots$

3. Do you take tip credit from employee pay check?

Answer: (a) Yes ......... (b) No ........

4. Comments: 


\section{APPENDIX D}

DETAILED: METROPOLITAN PORTLAND EXPENDITURES BY COUNTY $1980-81$

Name of Political Unit

Metropolitan Service District

Clackamas County

Cities

- Barlow

- Canby.

- Estacada

- Gladstone

- Happy Valley

- Johnson City

- Lake Oswego

- Milwaukie

- Molalla

- Oregon City

- River Grove

- Sandy

- West Linn

Sub-Total

Water Districts

- Barwell Park

- Boring Dist. \#24

- Clackamas
Expenditures

Sub-Total $14,039,725$

$48,866,022$

$$
\begin{gathered}
12,195 \\
5,156,923 \\
569,889 \\
2,068,583 \\
96,182 \\
32,454 \\
13,489.17 \\
5,522,013 \\
1,847,611 \\
5,983,392 \\
13,489.17 \\
1,718,082 \\
4,184,825
\end{gathered}
$$

100,899

79,132

$2,240,903$ 
- Clairmont

- Colton

- Damascus

- Forest Highland

- Holcomb-Outlook

- Mossy Brae

- Mulino Dist. \#23

- Oak Lodge

- Palatine Hill

- Park Place

- Red Land

- River Grove

- Southwood Park

- Wichita

Sub-Total

Rural Fire Protection Districts

- Beaver Creek

- Boring

- Canby

- Clackamas City Dist. \#1

- Clackamas City Dist. \#71

- Clackamas County Dist. \#54

- Clarkes

- Estacada

- Happy Valley

- Hoodland

- Lake Grove
523,202

127,808

300,282

39,832

$185,4 / 3$

1,758

44,888

787,354

147,937

71,559

250,945

170,025

19,851

58,807

$5,150,625$
200,779

452,987

255,631

$2,131,126$

$1,099,158$

979,415

73,442

293,328

463,022

303,014

260,305 
- Molalla

- Oak Lodge Dist. \#51

- Riverdale

- Sandy

Sub-Total

Service Districts

- Clackamas City Dist. \#1

- Clackamas City Dist. \#5

- Clackamas City Dist. \#6

- Hoodland

Sub-Total

Soil \& Conservation Districts

- Clackamas County S.W.C.D.

Sub-Total

Park and Recreation District

- Lake Grove Park
108,336

$1,153,374$

128,029

$9,596,317$

$$
\begin{array}{r}
2,340,217 \\
155,502 \\
2,184 \\
1,892,090
\end{array}
$$

$17,498,263$

$$
4,389,993
$$

$$
7,446
$$

$$
7,446
$$

45,132

Sub-Total

Sanitary and Vector Control Districts

- Clackamas County Vector Control

104,452

- Government Camp Sanitary

84,929

- Oak Lodge

869,443

Sub-Total

$1,058,824$

Multnomah County

$151,266,138$

Cities

- Fairview

334,140

- Gresham

$13,002,008$ 
- Maywood Park

- Portland

- Troutdale

- Wood Village

Sub-Total

Water Districts

- Alto Park

- Burlington

- Corbett

- Darlington

- Gilbert

- Hazelwood

- Lusted

- Parkrose

- Pleasant Home

- Powell Valley Road

- Richland

- Rockwood

- Rose City

- SyIvan

- Valley View

Sub-Total

Rural Fire Protection Districts

- Multnomah County Dist. \#1

- Multnomah County Dist. \#4

- Multnomah County Dist. \#10

- Multnomah County Dist. \#14

$$
\begin{array}{r}
47,459 \\
300,342,681 \\
2,084,754 \\
443,876
\end{array}
$$

$316,254,918$

$$
\begin{array}{r}
7,132 \\
47,896 \\
120,786 \\
21,090 \\
194,949 \\
1,030,283 \\
243,653 \\
877,774 \\
79,717 \\
1,042,287 \\
68,379 \\
3,006,159 \\
251,198 \\
135,757 \\
167,321
\end{array}
$$

$7,294,381$ 
- Multnomah County Dist. \#20 17,860

Sub-Total

$7,178,208$

Service Districts

- Central County

221,884

- Dunthorpe-Riverdale

59,631

- Mid County

$1,033,563$

- West Hills

31,149

Sub-Total

$1,346,227$

Soil and Conservation Districts

- East Multnomah S.W.C.D.

677

- West Multnomah S.W.C.D.

10,802

Sub-Total

11,479

Road Districts

- Sky Crest

184

Sub-Total

184

Drainage Districts

- Multnomah County

160,967

- Peninsula

157,090

- Sandy

5,945

Sub-Total

Washington County

324,002

$33,265,674$

Cities

- Banks

20,124

- Beaverton

$22,798,482$

- Cornelius

$1,165,353$

- Durham

68,347

- Forest Grove

$7,742,956$ 
- Gaston

- Hillsboro

- King City

- North Plains

- Sherwood

- Tigard

- Tualatin

- Wilsonville

Sub-Total

Water Districts

- Cooper Mountain

- Hillsboro-Forest Grove Jt. $\quad 302,868$

- Metzger

- Star Satellite Improvements

- Tigard

- West SIope

- Wolf Creek Highway

- Wolsborn Farm

Sub-Total

Rural Fire Protection District

- Cornelius

- Forest Grove

- Gaston

- Tri-city

- Tualatin

- Washington County Dist. \#1

- Washington County Dist. \#2

$$
162,576
$$

$19,061,182$

245,350

196,766

$1,172,732$

$4,592,519$

450,000

$4,789,083$
$1,590,311$

16,532

$1,983,441$

591,059

$6,767,587$

5,639

$$
\begin{array}{r}
28,485 \\
177,096 \\
71,140 \\
75,925 \\
6,459,855 \\
8,453,335 \\
339,595
\end{array}
$$

$11,260,274$ 
Sub-Total

$15,605,431$

Service Districts

- Unified Sewerage Agency of Washington County

$11,931,657$

- Washjington County Service District for Light

439,403

Sub-Total

$12,371,060$

Road Districts

- Rainbow Ln. SP Dist. \#1

853

Sub-Total

853

Drainage Districts

$\begin{array}{ll}\text { - Job's District } & 1,715\end{array}$

- Washington County Dist. \#8 2,728

Sub-Total

$$
4,443
$$

Parks and Recreation Districts
- Tualatin Hills
$5,028,428$

Sub-Total

$5,028,428$

TOTAL

$\$ 746,752,327.34$ 